University of Louisville

ThinkIR: The University of Louisville's Institutional Repository

Electronic Theses and Dissertations

8-2005

\title{
Groundwater remediation technologies for trichloroethylene and technetium-99.
}

John Nicholas Uhl 1960-

University of Louisville

Follow this and additional works at: https://ir.library.louisville.edu/etd

\section{Recommended Citation}

Uhl, John Nicholas 1960-, "Groundwater remediation technologies for trichloroethylene and technetium-99." (2005). Electronic Theses and Dissertations. Paper 1474.

https://doi.org/10.18297/etd/1474

This Master's Thesis is brought to you for free and open access by ThinkIR: The University of Louisville's Institutional Repository. It has been accepted for inclusion in Electronic Theses and Dissertations by an authorized administrator of ThinkIR: The University of Louisville's Institutional Repository. This title appears here courtesy of the author, who has retained all other copyrights. For more information, please contact thinkir@louisville.edu. 
GROUNDWATER REMEDIATION TECHNOLOGIES FOR TRICHLOROETHYLENE AND TECHNETIUM-99

\author{
By
}

John Nicholas Uhl III

B.A. University of Louisville, 1989

B.S. University of Louisville, 2004

\author{
A Thesis \\ Submitted to the Faculty of the \\ University of Louisville \\ Speed Scientific School \\ As Partial Fulfillment of the Requirements \\ For the Professional Degree
}

\title{
MASTER OF ENGINEERING
}

Department of Civil and Environmental Engineering 


\section{GROUNDWATER REMEDIATION TECHNOLOGIES FOR TRICHLOROETHYLENE AND TECHNETIUM-99}

Submitted by:

John Nicholas Uhl III

A Thesis Approved on

8-12-05

Date

By the Following Reading and Examination Committee:

D. J. Hagerty, Thesis Director

James C. Watters

J. P. Mohsen 


\section{ACKNOWLEDGEMENTS}

Successful completion of this thesis was possible only with the support of numerous dedicated individuals.

First and foremost, the author would like to thank his thesis director and graduate academic advisor, Dr. D. J. Hagerty, for his continuous support and guidance with this project and other course work. His insights, sources, and contacts throughout this project have been greatly valued. He always provided encouragement and feedback, and allowed the author to explore his interest and abilities. Dr. Hagerty has been instrumental in the completion of this work.

The author would also like to thank Dr. J. C. Watters for his support on the thesis committee and for reviewing this work during its development. His insights and answers to questions regarding chemistry and environmental processes have been valuable in the writing of this work.

Gratitude is also extended to Dr. J. P. Mohsen for serving on the thesis committee and as department chair, taking a genuine interest in the needs and future of students.

Special thanks to Dr. M. N. French for excellence in teaching of surface water and groundwater hydrology. His patience and support inside and outside the 
classroom gave the author the understanding of the topics necessary to complete this work.

The author would like to recognize The Department of Civil and Environmental Engineering at the University of Louisville and the administrative staff, particularly Leanne Whitney and Gail Graves for assistance regarding administrative issues.

The project was sponsored by the Kentucky Research Consortium for Energy and Environment (KRCEE).

Finally, innumerable thanks are given to the author's wife, Lisa Santos. Her patience, support and answers to his incessant computer questions have been integral to the completion of this work. 


\section{ABSTRACT}

The Technical Advisory Group (TAG) of the Innovative Treatment Remediation Demonstration Program (ITRD) made technology recommendations after reviewing thirty in situ remediation technologies for implementation at the Paducah Gaseous Diffusion Plant (PGDP) to treat groundwater contaminated with trichloroethylene (TCE) and technetium-99 (Tc-99). The 1999 data used in the ITRD final report were considered to be obsolete as of the year 2004. In this work, cost and performance of the ITRD recommended technologies were updated and compared to newer technologies not in the original review.

The technologies were described and case studies were used to evaluate cost and performance with costs brought up to 2005 values. Bioremediation and In Situ Chemical Oxidation (ISCO) methods proved to be the most effective technologies based on the case studies. Site assessment will determine what technology is the most feasible to implement from the bioremediation and ISCO choices. Permeable Reactive Barriers (PRB) can be effective in preventing contaminant migration. Humic products prove to be very effective on a laboratory scale and warrant further investigation. 
TABLE OF CONTENTS

APPROVAL PAGE

AKNOWLEDGEMENTS

ABSTRACT v v

NOMENCLATURE $\quad$ ix

LIST OF TABLES xiii

LIST OF FIGURES xiv

I. INTRODUCTION 1

$\begin{array}{ll}\text { A. Objective } & 1\end{array}$

$\begin{array}{ll}\text { B. Background } & 3\end{array}$

$\begin{array}{ll}\text { C. Study Parameters } & 7\end{array}$

II. REMEDIATION TECHNOLOGIES

$\begin{array}{ll}\text { A. Rotary Treatment } & 10\end{array}$

$\begin{array}{ll}\text { B. Soil Fracturing } & 10\end{array}$

$\begin{array}{ll}\text { C. Chemical Oxidation with Ozone } & 11\end{array}$

$\begin{array}{ll}\text { D. Chemical Oxidation with Permanganate } & 12\end{array}$

E. Chemical Oxidation with Fenton's Process 13 
$\begin{array}{ll}\text { G. Soil Vapor Extraction } & 18\end{array}$

$\begin{array}{ll}\text { H. Six-Phase Heating } & 19\end{array}$

I. Steam: Dynamic Underground Stripping and Hydrous Pyrolysis Oxidation 21

$\begin{array}{ll}\text { J. Bioremediation } & 22\end{array}$

K. Bioremediation Technology Selection and Implementation 26

L. Humic Products $\quad 32$

$\begin{array}{ll}\text { M. Nanotechnology } & 33\end{array}$

$\begin{array}{ll}\text { N. Permeable Reactive Barriers } & 35\end{array}$

III. TECHNOLOGY PERFORMANCE 41

A. Rotary Treatment $\quad 42$

B. Soil Fracturing $\quad 42$

C. Chemical Oxidation with Ozone 43

D. Chemical Oxidation with Permanganate 44

E. Chemical Oxidation with Fenton's Process 44

F. Chemical Oxidation with Peroxide Activated Sodium Persulfate 45

$\begin{array}{ll}\text { G. Soil Vapor Extraction } & 47\end{array}$

$\begin{array}{ll}\text { H. Six-Phase Heating } & 47\end{array}$

I. Steam: Dynamic Underground Stripping and Hydrous Pyrolysis Oxidation 49

$\begin{array}{ll}\text { J. Bioremediation } & 50\end{array}$

$\begin{array}{ll}\text { K. Nanotechnology } & 56\end{array}$

$\begin{array}{ll}\text { L. Permeable Reactive Barriers } & 57\end{array}$

IV. SUMMARY OF TECHNOLOGY PERFORMANCE 59 
$\begin{array}{ll}\text { A. Conclusions } & 65\end{array}$

B. Recommendations

$\begin{array}{ll}\text { VI. REFERENCES } & 70\end{array}$

APPENDIX A - ITRD COST AND PERFORMANCE ESTIMATES 74

APPENDIX B - FENTON'S PROCESS

APPENDIX C - DR. ALEXANDER SHULGIN'S HMA EXPERIMENTS

APPENDIX D - COST INFLATION 92

$\begin{array}{ll}\text { VITA } & 94\end{array}$ 
NOMENCLATURE

\begin{tabular}{|c|c|}
\hline ANA & Alliance for Nuclear Accountability \\
\hline AEHS & Association for Environmental Health and Science \\
\hline aq & aqueous \\
\hline BTEX & Benzene Toluene Ethylbenzene Xylene \\
\hline $\mathrm{CAH}$ & Chlorinated Aliphatic Hydrocarbon \\
\hline CES & Current Environmental Solutions \\
\hline $\mathrm{C}_{2} \mathrm{Cl}_{4}$ & Tetrachloroethylene \\
\hline $\mathrm{C}_{2} \mathrm{HCl}_{3}$ & Trichloroethylene \\
\hline $\mathrm{Cl}^{-}$ & Chlorine ion \\
\hline $\mathrm{cm} / \mathrm{s}$ & centimeters per second \\
\hline $\mathrm{CO}_{2}$ & Carbon Dioxide \\
\hline CRADA & Cooperative Research and Development Agreement \\
\hline $\mathrm{Cr}$ & Chromium \\
\hline DCE & Dichloroethylene \\
\hline DNAPL & Dense Non-aqueous Phase Liquid \\
\hline DUS & Dynamic Underground Stripping \\
\hline
\end{tabular}




\begin{tabular}{|c|c|}
\hline$e^{-}$ & electron \\
\hline $\mathrm{Fe}^{0}$ & Zero Valent Iron \\
\hline $\mathrm{Fe}^{2+}$ & Iron Ion \\
\hline $\mathrm{ft} /$ day & feet per day \\
\hline $\mathrm{H}^{+}$ & Hydrogen Ion \\
\hline $\mathrm{HCl}$ & Hydrochloric Acid \\
\hline HDPE & High Density Polyethylene \\
\hline $\mathrm{Hg}$ & Mercury \\
\hline $\mathrm{H}_{2} \mathrm{O}$ & Water \\
\hline $\mathrm{H}_{2} \mathrm{O}_{2}$ & Hydrogen Peroxide \\
\hline HPO & Hydrous Pyrolysis Oxidation \\
\hline $\mathrm{HSO}_{4}^{-}$ & Hydrogen Sulfate \\
\hline ISCO & In Situ Chemical Oxidation \\
\hline ITRC & Interstate Technology Regulatory Council \\
\hline ITRD & Innovative Treatment Remediation Demonstration Program \\
\hline $\mathrm{K}^{+}$ & Potassium Ion \\
\hline $\mathrm{K}$ & hydraulic conductivity \\
\hline $\mathrm{KMnO}_{4}$ & Potassium Permanganate \\
\hline LLNL & Lawrence Livermore National Laboratories \\
\hline $\mathrm{MnO}_{2}$ & Manganese Dioxide \\
\hline Mo & Molybdenum \\
\hline MTBE & Methyl Tertiary Butyl Ether \\
\hline na & not applicable \\
\hline
\end{tabular}


NAPL Non-aqueous Phase Liquid

$\mathrm{NaMnO}_{4} \quad$ Sodium Permanganate

NIS Newly Independent States

$\mathrm{NO}_{3}^{-} \quad$ Nitrate

$\mathrm{O}_{2} \quad$ oxygen

$\mathrm{O}_{3} \quad$ ozone

$\mathrm{OH} \bullet \quad$ Hydroxyl free radical

$\mathrm{OH}^{-} \quad$ Hydroxyl ion

OTD Office of Technology Development

PCE Tetrachloroethylene

PGDP Paducah Gaseous Diffusion Plant

$\mathrm{piC} / \mathrm{L} \quad$ picocurie per liter

ppb parts per billion

PRB Permeable Reactive Barrier

RGA Regional Groundwater Aquifer

s solid

SCRD State Coalition for Remediation of Drycleaners

$\mathrm{S}_{2} \mathrm{O}_{8}{ }^{-2} \quad$ Persulfate Anion

$\mathrm{SO}_{4} \bullet \quad$ Sulfate Radical

$\mathrm{SO}_{4}{ }^{-2} \quad$ Sulfate Ion

Sr-90 Strontium-90

SUBCON Subsurface Contaminant Focus Area

SVE Soil Vapor Extraction 


$\begin{array}{ll}\text { TAG } & \text { Technical Advisory Group } \\ \text { TCE } & \text { Trichloroethylene } \\ \text { Tc-99 } & \text { Technetium-99 } \\ \text { TOC } & \text { Total Organic Carbon } \\ \text { U } & \text { Uranium } \\ \text { UCRS } & \text { Upper Continental Recharge System } \\ \text { US DOE } & \text { United States Department of Energy } \\ \text { US EPA } & \text { United States Environmental Protection Agency } \\ \text { V } & \text { Volts } \\ \text { VC } & \text { Vinyl Chloride } \\ \text { VOC } & \text { Volatile Organic Carbon } \\ \text { WSRC } & \text { Westinghouse Savannah River Company }\end{array}$




\section{LIST OF TABLES}

Table II-1 Terminal Electron Accepting Process Related to Hydrogen

Concentration

Table II-2 Favorable and Unfavorable Site Conditions for Microbial

Remediation of CAHs and Engineered Solutions for Unfavorable Conditions

Table II-3 Primary Reactants and Additives for Microbial Engineered Systems

Table II-4 PRB Treatment Media for Different Treatment Methods

Table IV-1 Performance and Cost for Technology Case Studies

Table V-1 Technology Ranking

Table A-1 ITRD Cost and Performance Estimates for Application at Paducah

Table A-2 ITRD Preliminary Technology Applications by Geologic Unit

Table C-2 Dr. Alexander Shulgin's HMA Experiments 


\section{LIST OF FIGURES}

Figure I-1 Map of PGDP Location 4

Figure I-2 TCE Plume Map $\quad 5$

$\begin{array}{lr}\text { Figure I-3 Tc-99 Plume Map } & 6\end{array}$

Figure II-1 Typical Soil Vapor Extraction 19

Figure II-2 Plan View of a Well Layout for Steam Remediation 21

Figure II-3 Anaerobic Reductive Dechlorination of PCE to Ethylene 23

Figure II-4 Aerobic Oxidation of a CAH 24

Figure II-5 Cometabolic Aerobic Oxidation of a CAH 25

Figure II-6 Dimensions of a Permeable Reactive Barrier 35

Figure II-7 Examples of various types of PRBs 36

Figure III-1 Plan View of Test Area at Kelly Air Force Base 51 


\section{INTRODUCTION}

\section{A. Objective}

The objective of this study was to evaluate remediation technologies for the contaminated groundwater at the Department of Energy (DOE) Paducah Gaseous Diffusion Plant (PGDP). The primary contaminants of concern were the chlorinated solvent trichloroethylene (TCE) and the radionuclide technetium-99 (Tc-99). The Technical Advisory Group (TAG) of the Innovative Treatment Remediation Demonstration Program (ITRD) made technology recommendations in the Paducah Project Innovative Technology Review final report (ITRD 2000). The 1999 data used in the ITRD report were considered to be obsolete as of the year 2004. The cost and performance estimates of the recommended technologies needed to be updated, and compared to newer innovative technologies not considered in the ITRD review.

The TAG identified and reviewed thirty in situ remediation technologies that could be applied to the TCE and Tc-99 contamination at PGDP. The technology categories considered in this study included in situ treatment of contaminated slowly permeable soils in both the saturated and vadose zones; and in situ treatment of a contaminated highly permeable sand and gravel aquifer. The identified technologies were evaluated for general maturity, cost, and performance characteristics as they 
would apply to PGDP. The most promising technologies were reviewed further through engineering evaluations with several vendors. The results of the TAG review can be found in Table A-1 in the appendix.

The TAG made recommendations on treatment technologies to be implemented at PGDP based on their review. The ranking of technologies recommended for in situ treatment of contaminated slowly permeable soils in both the saturated and vadose zones was: rotary treatment; chemical oxidation-ozone/fracturing; direct heating; and SVE/fracturing. The ranking of technologies recommended for in situ treatment of a contaminated highly permeable sand and gravel aquifer was: chemical oxidation (CSparge); direct heating; Steam/ Dynamic Underground Stripping/Hydrous Pyrolysis Oxidation (DUS/HPO); and chemical oxidation (permanganate). Descriptions of these technologies are given in Chapter II.

In addition to the recommendations listed above, the TAG report evaluated characterization and pilot studies. The TAG suggested that a range of characterization technologies suitable for wide areas of contamination should be considered in order to optimize the overall remedial design in such areas. Deeper characterization and better characterization under buildings can help minimize remediation cost caused by difficulty of implementation.

The TAG endorsed the iron reactive wall pilot study that was planned for the PGDP site. The TAG also ranked the pilot studies needed for further study. Priority 1 consisted of: C-Sparge with ion exchange for Tc-99 in the highly permeable sand and gravel aquifer and fracturing with ozone in the slowly permeable soils. Priority 2 consisted of: direct heating (six-phase heating) and chemical oxidation using 
permanganate. These pilot studies were recommended to determine the feasibility of these technologies under specific site conditions at PGDP.

\section{B. Background}

The PGDP is located on approximately 3600 acres in western Kentucky near the Ohio River, with 750 acres located inside a security fence area. The plant area is situated 10 miles west of Paducah and about 3.5 miles south of the Ohio River. The map in Figure I-1 shows the PGDP location.

The PGDP began uranium enrichment operations in 1952 and became fully operational by 1955 . Initially the plant produced materials used in the U.S. nuclear weapons industry. Operations gradually expanded to include nuclear weapons disassembly and disposal, recovery of transuranics, exotic metals recovery, and uranium milling and recovery. Eventually the plant produced fuel for commercial nuclear power plants. Radioactive and hazardous wastes have been generated and disposed of at the site from previous disposal practices and plant operations. Improper disposal practices, accidental or deliberate releases, spills and leaching from buried waste materials have contributed to contamination of the soil and groundwater at the PGDP site. (ANA 2004 p 145-147)

Three large plumes of contaminated groundwater have migrated outside the plant boundaries. These plumes are referred to as the Northwest Plume, the Northeast Plume and the Southwest Plume. The two northern plumes are oriented toward the Ohio River. The primary contaminants in all three plumes are TCE, an industrial degreasing solvent, and Tc-99, a fission byproduct of uranium enrichment. (ITRD 2000 
p 7) The maps in Figure I-2 and Figure I-3 show the TCE and Tc-99 plumes respectively.

Figure I-1 Map of PGDP Location (US DOE 2001 p 1-10)

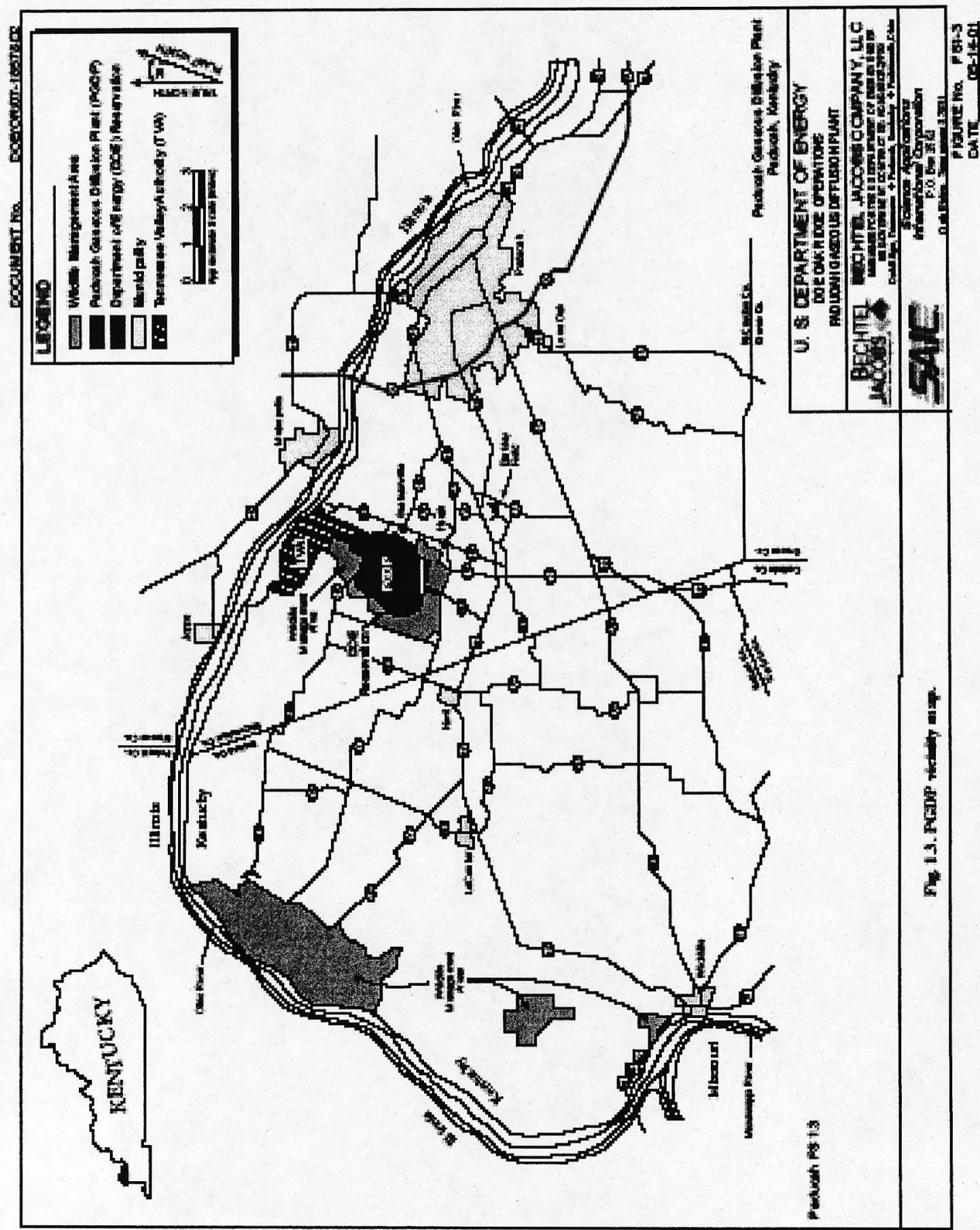


Figure I-2 TCE Plume Map (US DOE 2001 p ES-8)

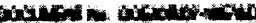

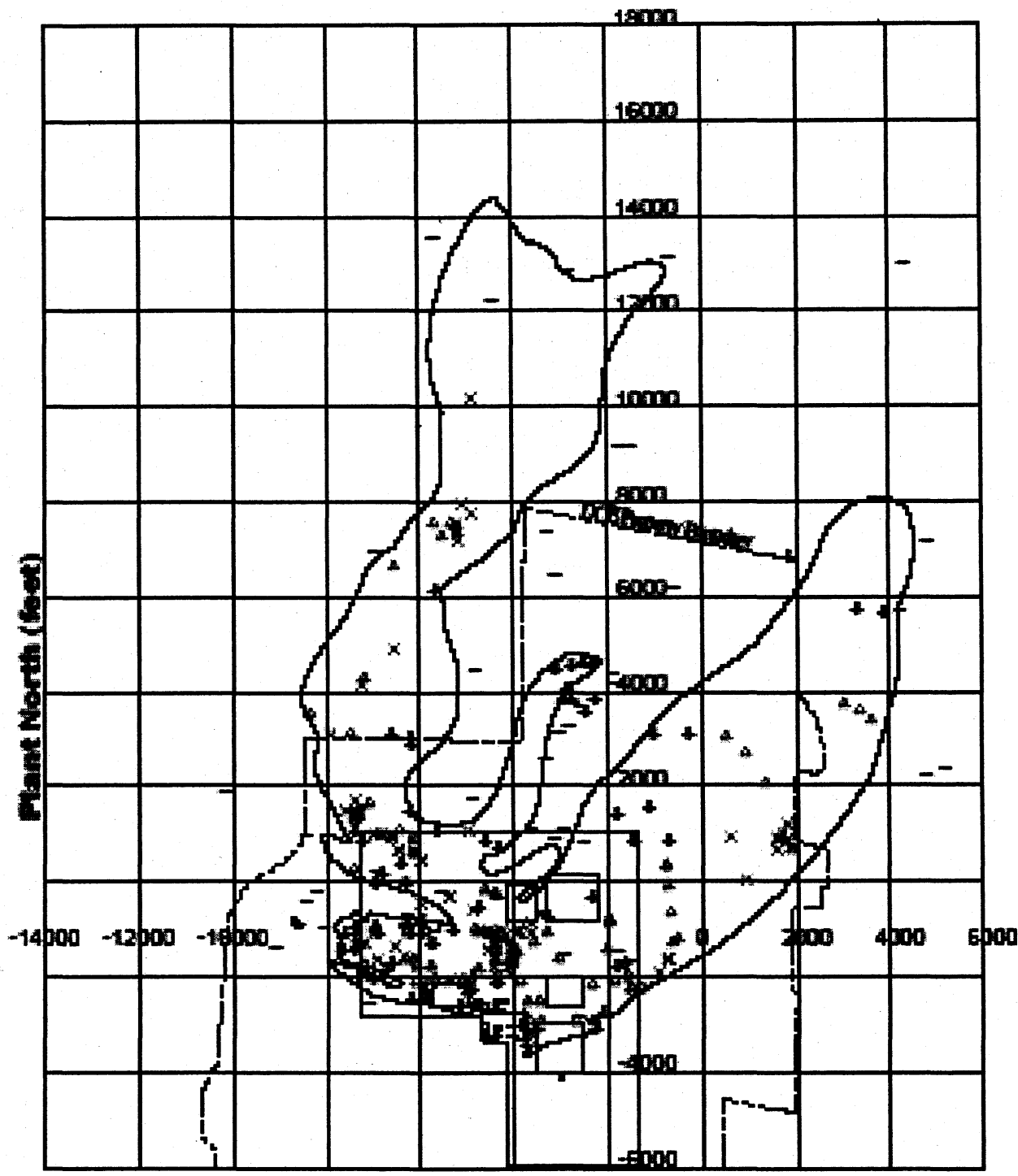

Pland Eat (fort)

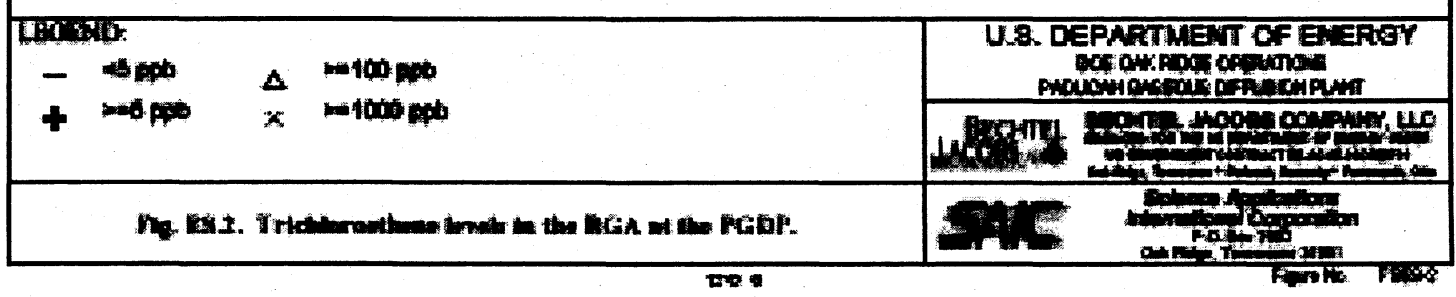


Figure I-3 Tc-99 Plume Map (US DOE 2001 p ES-11)

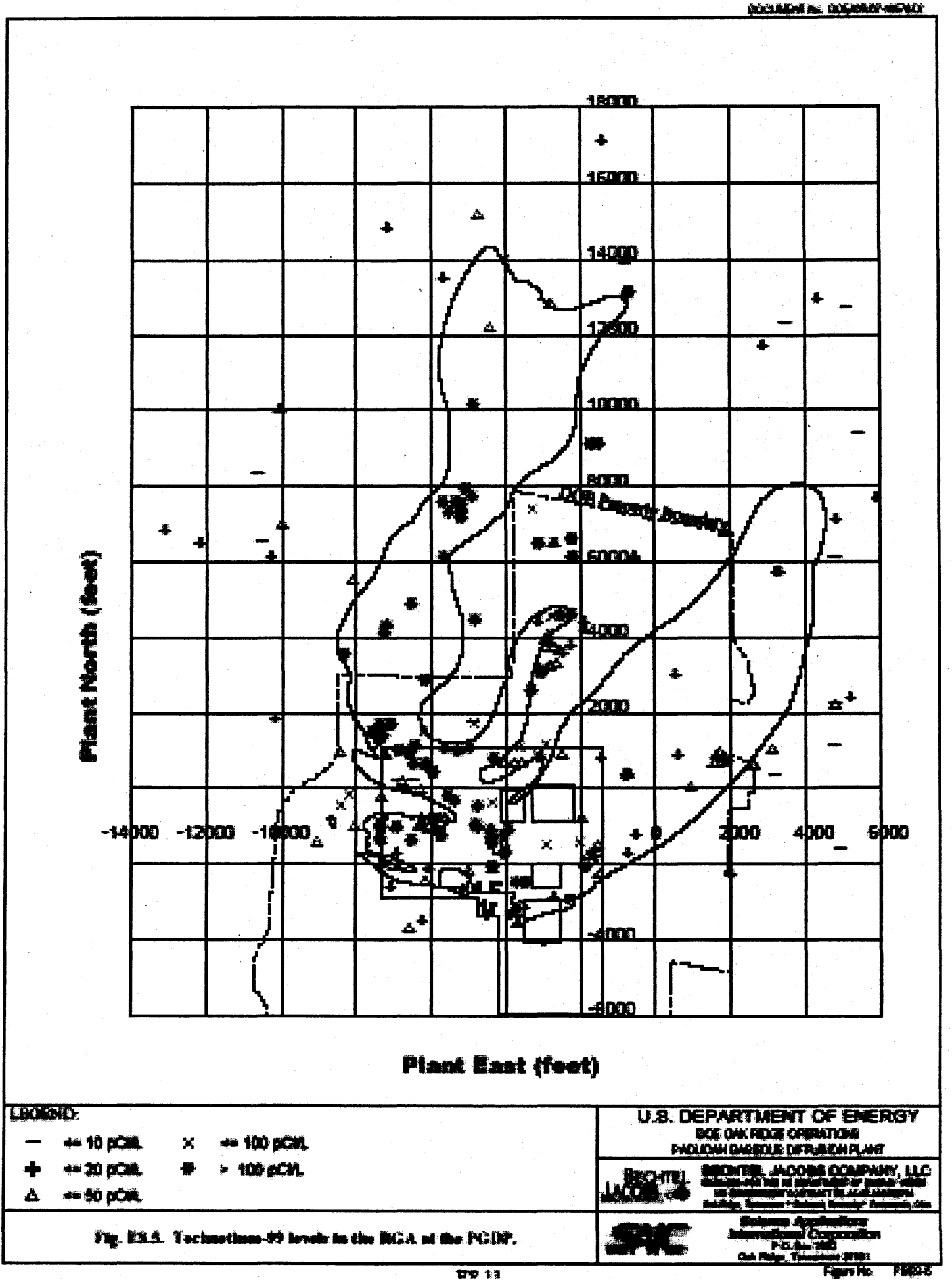


The unconsolidated geologic units of interest found beneath the site are listed from ground surface to the lowest unit as the Upper Continental Recharge System (UCRS), the Regional Groundwater Aquifer (RGA), and the McNairy formation. (ANA $2004 \mathrm{p}$ 146) The UCRS is the top sixty feet, consisting of low permeability silt and clay lenses with hydraulic conductivity ranging from 0.01 to $0.28 \mathrm{ft} /$ day. The water table at the site can vary from 10 to 30 feet deep. Below the UCRS is the RGA, an aerobic sandy-gravel aquifer with hydraulic conductivity ranging from 1 to $3 \mathrm{ft} /$ day. The RGA varies in thickness from about 30 to 60 feet. The McNairy formation is a semiconfining layer underlying the RGA.

The contaminant levels at the DOE boundaries include TCE concentrations up to $10 \mathrm{ppm}$ and $\mathrm{Tc}-99$ concentrations up to $1000 \mathrm{piC} / \mathrm{L}$. The drinking water standards are $5 \mathrm{ppb}$ for TCE and $900 \mathrm{piC} / \mathrm{L}$ for Tc-99. (ITRD $2000 \mathrm{p} \mathrm{6)}$

\section{Study Parameters}

The complexity of the hydrologic and infrastructure issues at the PGDP site led the TAG to separate the summary of the technology review into two categories: technologies for treatment or containment of contaminants in low permeability vadose soils; and technologies for treatment of saturated low permeability and high permeability soils and groundwater. The TAG also considered the different contaminant concentration levels to be treated, which included higher concentrations near the source and lower concentrations in the plumes. Table A-2 in the appendix shows the technologies considered in these categories. 
The TAG did not consider treatment of Tc-99 in the vadose zone because they believed that after the TCE source was removed, Tc-99 would not be mobile and Tc-99 in the groundwater was of more concern than Tc-99 in the vadose zone. According to the TAG, there was indication from regulators that removal of TCE from the vadose zone would be adequate remediation without addressing Tc-99 in the vadose zone. (ITRD 2000 p 13)

Chapter II describes the remediation technologies, how they work physically and how they can be applied to the appropriate location. That chapter also describes how the technologies were evaluated. The factors considered by the TAG included: implementation cost and ease of implementation; technology maturity and appropriateness; life-cycle costs and overall cost-effectiveness; ability to reduce the contaminants to regulatory levels of compliance; compatibility with existing site constraints and treatment systems; stakeholder considerations; and regulatory permits.

Chapter III describes the most current full-scale and pilot studies utilizing the technologies being considered for PGDP. The factors for each technology were determined from the full-scale and pilot studies investigated.

Chapter IV summarizes the results from Chapter III and considers site assessment necessary for technology selection. Chapter V presents conclusions and recommendations based on the Chapter IV summary and assessment considerations. 


\section{REMEDIATION TECHNOLOGIES}

In previous chapter, the objective, background, and study parameters were presented. In this chapter, descriptions of the relevant technologies are presented, describing how they can be applied to the PGDP site. The TAG ranking of technologies recommended for in situ treatment of contaminated low permeability soils in both the saturated and vadose zones were rotary treatment; chemical oxidation-ozone with fracturing; direct heating (six phase heating); and soil vapor extraction (SVE) with fracturing. The ranking of technologies recommended for in situ treatment of a contaminated highly permeability sand and gravel aquifer was chemical oxidation (CSparge); direct heating; Steam Treatment by Dynamic Underground Stripping (DUS) or Hydrous Pyrolysis Oxidation (HPO); and chemical oxidation (permanganate).

In addition to revisiting the TAG recommended technologies, this work compares peroxide activated sodium persulfate and Fenton's process to the other in situ chemical oxidation (ISCO) methods using permanganate and ozone. Bioremediation, humic, nanotechnology and permeable reactive barriers (PRBs) are considered as other newer developing technologies. 


\section{A. Rotary Treatment}

This method uses augers to mix soil with a reactive agent such as steam, ozone, permanganate, or iron filings. (ITRD $2000 \mathrm{p} 15$ ) Rotary steam stripping uses steam to volatilize volatile organic contaminants (VOCs) such as TCE and force them to the surface. When steam is condensed the VOCs are collected and absorbed using activated carbon. Rotary treatment also can be used with an oxidizing agent such as permanganate or ozone to treat the VOCs in situ. Reactive media, such as zero-valent iron, can be used with rotary treatment to immobilize Tc-99.

Rotary treatment can be applied to contaminated low permeability soils in both the saturated and vadose zones with high levels of contaminants (up to $300,000 \mathrm{ppm}$ VOCs). Treatment depths up to 70 feet are possible with effective treatment areas of 40 to 75 square feet per bore hole. Treatment rates range from 20 to 40 cubic yards per hour with contaminant removal efficiencies of 80 to 90 percent. (ITRD $2000 \mathrm{p} 15$ )

\section{B. Soil Fracturing}

Pneumatic and hydraulic fracturing of low permeable soils can enhance the performance of extraction or injection wells. (US DOE 2000 p 1) Pneumatic fracturing involves the injection of highly pressurized gas (nitrogen or air) into the soil via bore holes to extend existing fractures and create a secondary network of subsurface channels. Hydraulic fracturing uses water or slurry instead of gas. Soil fracturing can extend the range of treatment when combined with other technologies such as bioremediation, chemical oxidation/reduction or soil vapor extraction. (US DOE $2000 \mathrm{p}$ 6-1) 


\section{Chemical Oxidation with Ozone}

Ozone $\left(\mathrm{O}_{3}\right)$ is a strong oxidizing agent having an oxidation potential about 1.2 times that of hydrogen peroxide. Because of its instability, ozone typically is generated on site and delivered to the contaminated zone through sparge wells. Air containing up to 5 percent ozone is injected through strategically placed sparge wells. Ozone dissolves in the groundwater and oxidizes the contaminant while decomposing to oxygen $\left(\mathrm{O}_{2}\right)$. Pneumatic fracturing can be used to enhance ozone effectiveness in low permeability soils. (US EPA May 2004 pp. XIII-11 and 12)

Ozone is ten times more soluble in water than is oxygen; therefore the groundwater becomes replete with dissolved oxygen as the unstable ozone molecules decompose into oxygen. Approximately half of the ozone introduced into the subsurface decomposes into oxygen within 20 minutes of injection. Rapid decomposition into oxygen can aid in bioremediation by creating an oxygen-rich environment for aerobic bacteria.

C-Sparge is an ozone oxidation technology developed by Kerfoot Technologies, Inc. (AEHS $2001 \mathrm{p} \mathrm{1)} \mathrm{C-Sparge} \mathrm{is} \mathrm{a} \mathrm{patented} \mathrm{ozone} \mathrm{microsparging} \mathrm{technology} \mathrm{for} \mathrm{in}$ situ treatment of VOCs. In this process ozone and air are injected into the groundwater through specially designed spargers to create nano-size to micro-size bubbles of airencapsulated ozone. The VOCs are extracted from the aqueous solution into small bubbles where they are oxidized by the encapsulated ozone, producing carbon dioxide $\left(\mathrm{CO}_{2}\right)$, oxygen $\left(\mathrm{O}_{2}\right)$ and water $\left(\mathrm{H}_{2} \mathrm{O}\right)$. The system can be applied to soil with hydraulic conductivities ranging from 1000 to $0.01 \mathrm{ft} /$ day. (Kerfoot 2005) Kerfoot Technologies 
claim that sites can be cleaned in one quarter to one third of the time required for typical pump-and-treat systems, at a cost reduction of 20 to 50 percent.

\section{Chemical Oxidation with Permanganate}

Potassium permanganate $\left(\mathrm{KMnO}_{4}\right)$ is the preferred chemical form of permanganate for oxidation because it is more widely available and less costly than sodium permanganate and is available in a solid form which allows for safer handling. A liquid form of sodium permanganate $\left(\mathrm{NaMnO}_{4}\right)$ is also available, but is more expensive than potassium permanganate. Permanganate can be delivered to the contaminated zone by injection probes, soil fracturing, soil mixing and ground water recirculation. (US EPA May 2004 p XIII-10)

Despite having less oxidation potential than hydrogen peroxide, potassium permanganate can react in environments with higher $\mathrm{pH}$ and can exist longer (hours to days) in these environments than hydrogen peroxide. For field application, potassium permanganate is shipped as a gray powder and is dissolved in water creating a purple liquid. The purple color can be used as an indicator of unreacted potassium permanganate. The reacted permanganate is dark brown to black, indicating the presence of manganese dioxide $\left(\mathrm{MnO}_{2}\right)$, a compound that is commonly found in soils. (Jacobs $2001 \mathrm{p}$ 7) Temperature influences the solubility of potassium permanganate, and at $30^{\circ} \mathrm{C}, \mathrm{KMnO}_{4}$ can be present at a concentration slightly over 8 percent. (ITRC Jan. $2005 \mathrm{p}$ 5) The following equation represents the chemical oxidation of TCE using potassium permanganate:

$$
2 \mathrm{KMnO}_{4}+\mathrm{C}_{2} \mathrm{HCl}_{3} \rightarrow 2 \mathrm{MnO}_{2}+2 \mathrm{CO}_{2}+3 \mathrm{Cl}^{-}+\mathrm{H}^{+}+2 \mathrm{~K}^{+}
$$


Three properties that could cause concern to the owner, operators or state regulators monitoring remediation should be considered when selecting potassium permanganate for application at a site: (US EPA May 2004 p XIII-10)

1. The potassium ores from which potassium permanganate is derived typically contain salt and metal impurities such as arsenic, chromium, and lead. These impurities may be a concern depending on the water quality criteria and the amount of potassium permanganate being used at the site (This limitation is also pertinent for sodium permanganate since it is mined and processed in a similar fashion.);

2. Since potassium permanganate is used to manufacture pharmaceuticals, its use should be monitored carefully, to preclude theft and misuse;

3. The flowable form of potassium permanganate contains silica, which can accumulate in wells and plug screens.

Despite those concerns, permanganate has three advantages over other oxidants: (US EPA May 2004 p XIII-10)

1. It oxidizes organics over a wider $\mathrm{pH}$ range;

2. It reacts over a longer period in the subsurface which allows the oxidant to permeate the soil and contact adsorbed contaminants more effectively; and

3. It does not typically produce heat, steam and vapors that may cause health and safety concerns.

\section{E. Chemical Oxidation with Fenton's Process}

Hydrogen peroxide $\left(\mathrm{H}_{2} \mathrm{O}_{2}\right)$, discovered in the late 1700 s, was one of the first chemical oxidants to be used in industry and was commercialized in the early 1800 s. 
Hydrogen peroxide works as a remedial chemical oxidant in two ways: direct chemical oxidation as hydrogen peroxide; and free radical production.

The exothermic and violent reaction of hydrogen peroxide with iron salts (ferrous sulfate) was described by a British professor, H. J. H. Fenton, in 1894. This process, known as Fenton's chemistry (or Fenton's reagent), utilizes a transition metal catalyst or an acid to enhance chemical oxidation reaction of hydrogen peroxide by producing the hydroxyl radical. (Jacobs and Testa 2003 p 4)

The most common field applications in chemical oxidation have been based on Fenton's Reagent, where hydrogen peroxide $\left(\mathrm{H}_{2} \mathrm{O}_{2}\right)$ is applied with an iron catalyst $\left(\mathrm{Fe}^{2+}\right)$, creating a hydroxyl free radical $(\mathrm{OH} \bullet)$. When peroxide is injected at concentrations of 10 percent to 35 percent into the subsurface, the hydroxyl free radical oxidizes the VOCs to carbon dioxide $\left(\mathrm{CO}_{2}\right)$ and water. Iron can occur naturally in some soil types in different forms. (Hem p114) The iron that is occurring naturally in the soil and groundwater, or added during the injection, catalyzes this reaction. The residual hydrogen peroxide decomposes into oxygen and water, and the remaining iron precipitates. (Jacobs and Testa 2003 p 5) The following reaction sequence represents the role of the iron catalyst with hydrogen peroxide in Fenton's process:
(1) $\mathrm{Fe}^{2+}+\mathrm{H}_{2} \mathrm{O}_{2} \rightarrow \mathrm{Fe}^{3+}+\mathrm{OH}^{-}+\mathrm{OH} \bullet$
(2) $\mathrm{Fe}^{3+}+\mathrm{H}_{2} \mathrm{O}_{2} \rightarrow \mathrm{Fe}^{2+}+\mathrm{H}^{+}+\mathrm{OOH}$
(3) $\mathrm{OH} \bullet+\mathrm{H}_{2} \mathrm{O}_{2} \rightarrow \mathrm{H}_{2} \mathrm{O}+\mathrm{OOH} \bullet$
(4) $\mathrm{OH} \bullet+\mathrm{Fe}^{3+} \rightarrow \mathrm{Fe}^{2+}+\mathrm{OH}^{-}$

Appendix $B$ gives a more detailed version of this reaction process. 
This process is capable of self-generating oxidants (primarily $\mathrm{OH}$ radical, $\mathrm{OOH}$ radical and oxygen species) when catalyzed by ferrous iron. In reaction (1), hydrogen peroxide oxidizes the iron to yield the $\mathrm{OH}$ radical. In reaction (2), hydrogen peroxide reduces the iron, regenerating the iron catalyst. (US DOE $1999 \mathrm{p}$ 9)

The oxidation reaction for TCE forms several unstable daughter products such as epoxides, which break down to aldehydes and ketones, then finally decomposing to carbon dioxide, chloride ions and water. The following reaction shows the results of this oxidation: (Jacobs and Testa 2003 p5)

$$
4 \mathrm{OH} \bullet+\mathrm{C}_{2} \mathrm{HCl}_{3} \rightarrow 2 \mathrm{CO}_{2}^{-}+3 \mathrm{Cl}+5 \mathrm{H}^{+}
$$

The $\mathrm{pH}$ of the surrounding medium increases as the reaction process continues; therefore, it is necessary to lower the $\mathrm{pH}$ with acids. Organic acids should be avoided since they have a tendency to increase side reactions. The optimal $\mathrm{pH}$ range is from 3.5 to 5.0 .

The exothermic nature of the oxidation process causes a rise in subsurface temperature. A rise in temperature above $60^{\circ} \mathrm{C}$ decomposes the peroxide. Conditions can become explosive and unsafe if temperatures rise above $82^{\circ} \mathrm{C}$. Field research determined the optimal reaction temperature to be in the range of 35 to $41^{\circ} \mathrm{C}$. (Jacobs and Testa 2003 p6) The temperature of subsurface reactions can be monitored and controlled by adding water, adjusting catalyst or oxidant concentrations, and reducing injection pressures.

Despite $\mathrm{pH}$, temperature and other safety concerns; the hydroxyl radical produced from Fenton's process is one of the most potent oxidative species known. The reaction time for remediation is very fast and the process is relatively inexpensive. As 
for any chemical oxidation process, careful evaluation of the site conditions concerning the physical and chemical properties of the soil and groundwater are required to implement Fenton's process properly as a remediation technology.

\section{F. Chemical Oxidation with Peroxide Activated Sodium Persulfate}

Chemical oxidation of chlorinated organics such as TCE using persulfate is one of the latest emerging remediation technologies. (Block et al 2004 p 1) Persulfates have been used in many applications such as initiating emulsion polymerization reactions, clarifying swimming pools, bleaching hair, micro-etching copper printed circuit boards, and total organic carbon (TOC) analysis. Persulfate salts dissociate in water to persulfate anions $\left(\mathrm{S}_{2} \mathrm{O}_{8}{ }^{-2}\right)$. Persulfates are usually available as sodium, potassium and ammonium salts. For groundwater remediation, potassium persulfate is not a good choice because of its low solubility in water. Ammonium persulfate can lead to generation of ammonia, which is regulated in groundwater. Therefore, sodium persulfate is the best choice as a chemical oxidant in the treatment of soil and groundwater contamination. (ITRC Jan. 2005 p 7)

The persulfate anion is one of the strongest oxidants used in remediation. The following reaction has an oxidation-reduction potential of $2.1 \mathrm{~V}$ :

$$
\mathrm{S}_{2} \mathrm{O}_{8}^{-2}+2 \mathrm{H}^{+}+2 e^{-} \rightarrow 2 \mathrm{HSO}_{4}^{-}
$$

This potential is slightly lower than that of ozone at $2.2 \mathrm{~V}$, but greater than that of the permanganate ion at $1.7 \mathrm{~V}$ and that of hydrogen peroxide at $1.4 \mathrm{~V}$.

As in the hydroxyl radical reactions produced by Fenton's process, sodium persulfate can be activated to form sulfate radicals $\left(\mathrm{SO}_{4} \bullet \bullet\right)$. The sulfate radical 
formation can be activated using various initiators such as heat or transition metal catalysts. The following reaction shows how the sulfate radical is formed.

$$
\mathrm{S}_{2} \mathrm{O}_{8}^{-2}+\text { initiator } \rightarrow \mathrm{SO}_{4}^{-} \bullet+\left(\mathrm{SO}_{4} \bullet \text { or } \mathrm{SO}_{4}^{-2}\right)
$$

The sulfate radical and the hydroxyl radical are very strong aqueous oxidizing agents, having redox potentials of $2.6 \mathrm{~V}$ and $2.7 \mathrm{~V}$, respectively. In addition to oxidation strength, persulfate (and sulfate radical) oxidation has several advantages over the other chemical oxidation technologies: (Block et al 2004 p 1)

1. Faster reaction time when compared to other oxidants;

2. The sulfate radical is more stable than the hydroxyl radical and therefore able to be transported over longer distances in the subsurface; and

3. Compared to the permanganate ion, persulfate has less affinity for organics in soil and therefore is more efficient in highly organic soils.

The sulfate radical initiation methods have been shown to be effective in lab scale studies but have limitations in field applications. Heat activation requires installation of a system to heat the aquifer to a desired temperature. Therefore, heat initiation is not practical because of high capital expenditures and additional operating costs. In general, heating is used for source treatment where the target area is smaller. The problem with iron activation is that iron transport capabilities are limited because iron II is oxidized to iron III by the persulfate, and at $\mathrm{pH}$ above 4, iron III is insoluble in water.

Because of the limitations of heat and iron catalysis to initiate sulfate radical formation, newer activation systems were developed. The criteria for the improved persulfate activation systems included: 
1. The initiator must be transportable in a groundwater system.

2. The initiator should increase the reactivity of persulfate in a wide range of organic contaminants.

3. The system should be easy to apply in a variety of subsurface conditions.

One of the new activation systems has proven to be very effective in TCE removal. (Block et al 2004 p 4) A dual oxidation system using hydrogen peroxide and sodium persulfate was developed by FMC-Orin in 2003. This system combines the reactivity of peroxide in the reduction of the contaminant with the enhanced stability of persulfate. The hypothesis is that hydrogen peroxide and persulfate have synergistic effects. The hydroxyl radicals from hydrogen peroxide can initiate the development of persulfate radicals, while the sulfate radicals can promote the development of the hydroxyl radicals. Hydrogen peroxide can break down the more reactive contaminants quickly, allowing the sulfate radicals to degrade the more recalcitrant contaminants. The multi-radical attack mechanism of peroxide and sulfate radicals provides a higher efficiency in destroying contaminants and permits the more recalcitrant contaminants to be more readily degraded. (Block et al 2004 p 4)

\section{G. Soil Vapor Extraction (SVE)}

Soil vapor extraction (SVE) is a remediation technology that uses a vacuum applied to an extraction well to remove vapor phase VOCs from the vadose zone. (ITRD 2000 p13)The extracted vapor typically is removed with carbon adsorption although other treatments such as chemical oxidation can be used. The three types of SVE that are available commercially consist of Passive SVE, Standard SVE (5-10 
inches $\mathrm{Hg}$ vacuum) and High Vacuum SVE (15-29 inches $\mathrm{Hg}$ vacuum). High Vacuum SVE typically is used in tight vadose zone soils having hydraulic conductivities ranging from 0.64 to $0.59 \mathrm{ft} /$ day. Soil fracturing can enhance SVE for soils with hydraulic conductivities lower than this range. High Vacuum SVE has been applied successfully to soils with permeabilities as low as those in the UCRS.

This technology by itself is used only above the water table, although when combined with other technologies that volatilize the contaminants below the water table, SVE can remove VOCs from greater depths. Figure II-1 shows a cross-section of a typical SVE set up.

Figure II-1. Typical Soil Vapor Extraction (Suthersan 1999)

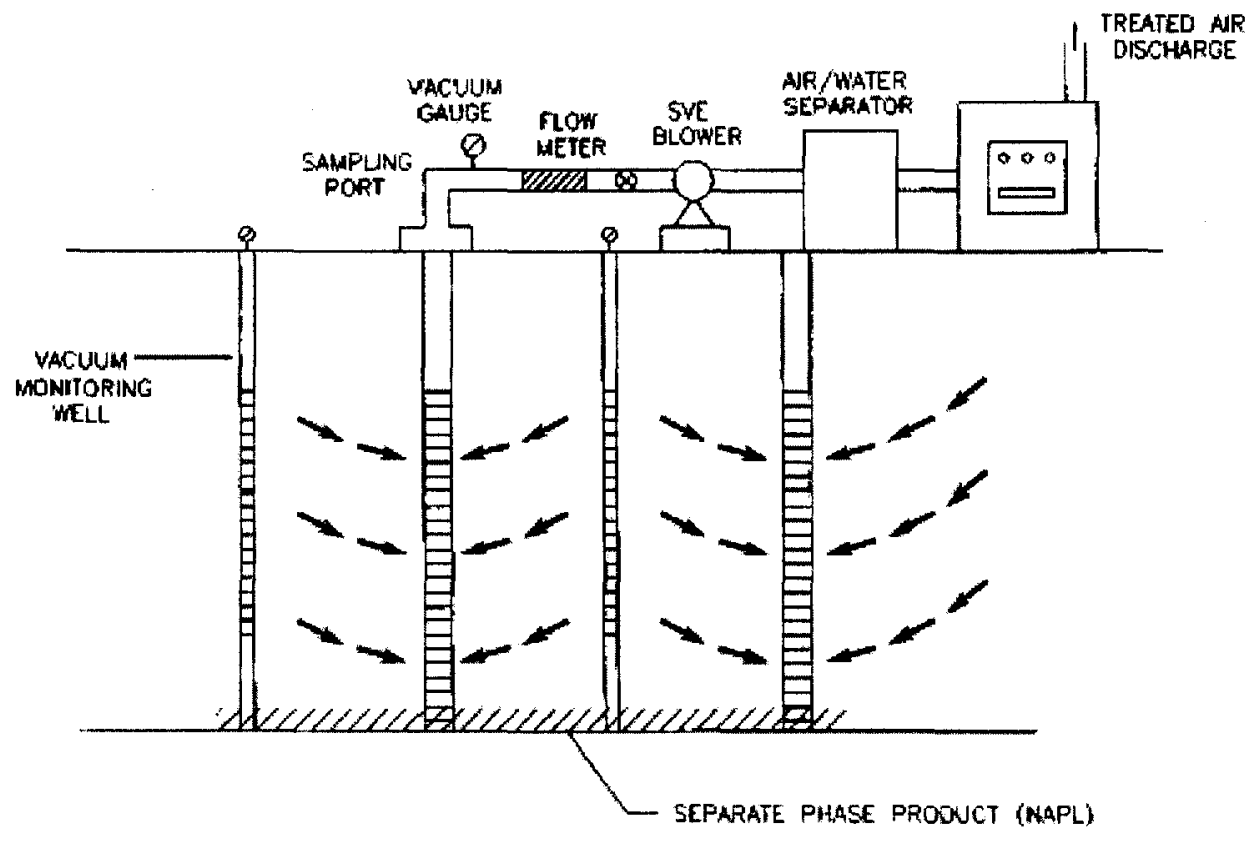

\section{H. Six-Phase Heating}

Six-phase heating is a patented direct heating remediation technology available through Current Environmental Solutions (CES 2005) used to increase the efficiency of 
SVE. (ITRD $2000 \mathrm{p} \mathrm{14}$ ) This method uniformly heats the soil in the subsurface, volatilizing the VOCs to be removed by SVE. The CES technology uses six electrodes positioned in a hexagonal array with a SVE well in the center of the hexagon. The array of electrodes has a typical array diameter of 25 to 35 feet with the diameter of the heating zone being about 40 percent larger than the array diameter. Electrical current from the electrodes passes through the soil. The soil matrix is used as a resistive component which emits heat. The factors that govern the resistance between electrodes include: soil type; moisture content; and distance between electrodes. With soil type and distance between electrodes fixed, regulating moisture content and applied voltage can control current flow. (CES 2005)

When the voltage is applied to the electrodes, the current will flow through the path of least electrical resistance, causing the soil to heat in those locations first. As the subsurface soil temperature approaches the boiling point of water, the VOCs with boiling points lower than $100^{\circ} \mathrm{C}$ volatilize. The soil moisture is removed as steam by SVE. The resistance increases as the soil dries, causing the current to flow through other more preferential pathways. This effect redirects the heat to the remaining contaminated locations. This automatic redirection allows for uniform heating over time even with heterogeneous soil. (CES 2005)

This technology can be applied to highly contaminated locations in low permeability soils. A pilot study was conducted at the PGDP with electrodes installed to a depth of 99 feet below ground surface. The results of this study are described in Chapter III. 


\section{Steam: Dynamic Underground Stripping (DUS) and Hydrous Pyrolysis}

\section{Oxidation (HPO)}

Steam flushing technology was developed originally for increasing the productivity of oil wells and oil fields. (WSRC 2001 p 11) Oil or DNAPL removal involves concentrating the liquid phase along the expanding steam front and collecting it from collection wells. Steam delivers heat and sweeps residual DNAPL from the subsurface using a set of delivery and collection wells. To minimize the potential for the plume to spread, the collection wells typically are located on the interior in the plan view of the well layout. Figure II- 2 shows a plan view for the well layout of a steam remediation.

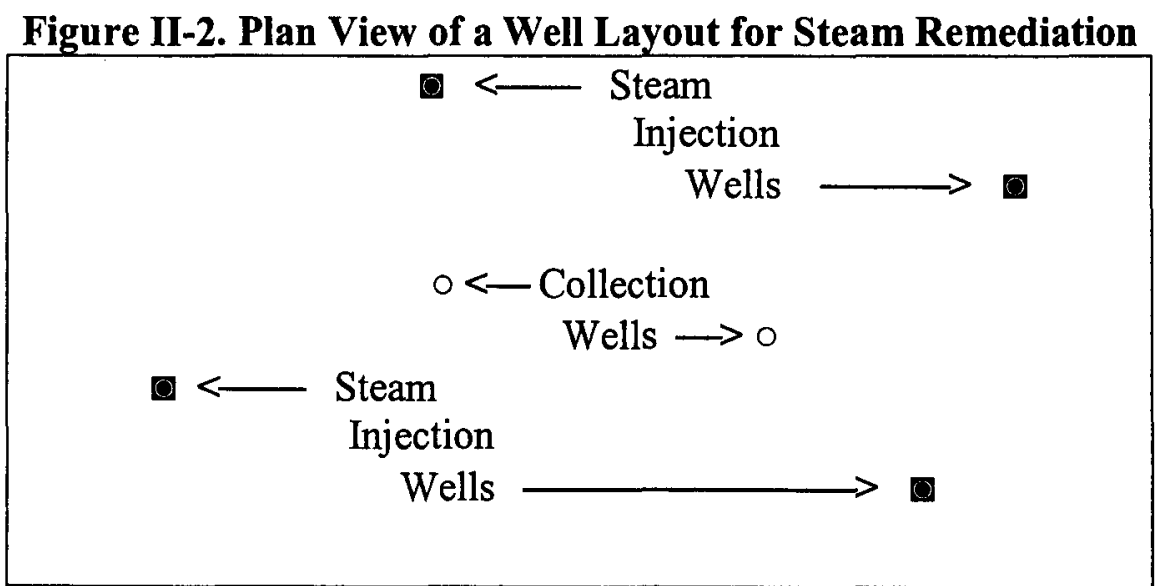

Steam raises the temperature of the soil and groundwater and increases the DNAPL component solubility and vapor pressure, as well as providing the heat energy to increase the mass transfer of contaminants from fine-grained soils. A benefit of steam heating and of other in situ heating methods is that part of the organic phase breaks down in the subsurface in the presence of oxygen and heat. 
In this technology, operators alternately inject oxygen and low pressure steam into the contaminated location. This injection produces a thermal destruction zone for the contaminated groundwater flowing into this zone. Using lower pressures when injecting steam encourages the steam to move more horizontally, instead of vertically upward.

The most successful and widely used of the commercially available steam technologies are: Dynamic Underground Stripping (DUS) for the steam sweep phase and Hydrous Pyrolysis Oxidation (HPO) for the abiotic action phase. (WSRC $2001 \mathrm{p}$ 12) These processes were developed with the support of the DOE Office of Technology Development (OTD) and Subsurface Contaminant Focus Area (SUBCON) and are licensees of the Lawrence Livermore National Laboratory (LLNL).

Compared to other thermal technologies, steam heating reduces the required number of access points because of the rapid expansion of steam. Steam works best in highly permeable soils such as those in the RGA. Horizontal drilling can be used to remediate under buildings and other obstacles. (ITRD $2000 \mathrm{p} 27$ )

Limitations on using this technology near the surface include elevated temperature and pressure, and the need for proper overburden characterization to prevent steam breakthrough.

\section{J. Bioremediation}

Under anaerobic conditions, microbes use the chlorinated aliphatic hydrocarbons (CAHs) such as TCE as electron acceptors in energy-producing redox reactions. The microbes gain energy and grow as one or more chlorine atoms are 
replaced with hydrogen. The hydrogen typically is supplied indirectly as the result of the fermentation of organic substrates. Figure II-3 shows the step by step reduction of tetrachloroethylene (PCE) to ethylene in the presence of hydrogen.

Figure II-3. Anaerobic Reductive Dechlorination of PCE to Ethylene (US EPA 2000 p 2-15)

\begin{tabular}{|c|c|c|c|c|c|c|c|c|c|}
\hline & \multicolumn{3}{|c|}{$\mathrm{H}_{2} \rightarrow \mathrm{HCl}$} & \multicolumn{2}{|c|}{$\mathrm{H}_{2} \rightarrow \mathrm{HCl}$} & \multicolumn{2}{|c|}{$\mathrm{H}_{2} \rightarrow \mathrm{HCl}$} & \multicolumn{2}{|c|}{$\mathrm{H}_{2} \rightarrow \mathrm{HCl}$} \\
\hline & PCE & $\rightarrow$ & TCE & $\rightarrow$ & DCE & $\rightarrow$ & VC & $\rightarrow$ & Ethylene \\
\hline Carbon & & & & & & & & & \\
\hline Oxidation & +2 & & +1 & & 0 & & -1 & & -2 \\
\hline State & & & & & & & & & \\
\hline Reduced & Mos & iic & & & & 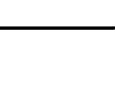 & & $\longrightarrow$ & Most \\
\hline
\end{tabular}

Dechlorination of the more highly chlorinated CAHs such as PCE and TCE occurs more readily than dechlorination of the more reduced CAHs such as dichloroethylene (DCE) and vinyl chloride (VC). In anaerobic environments, DCE and VC can accumulate while PCE and TCE are being directly reduced by anaerobic microbes. According to the National Institute for Occupational Safety and Health (NIOSH) there no allowable exposure limit to VC and 1,1-DCE. Even though 1,2-DCE has an allowable exposure limit twice that of PCE and TCE, it is still a concern due to the fact that it could degrade to VC. To overcome this problem, the idea of using a cometabolite was developed. (US EPA 2000 p 2-15)

Cometabolic anaerobic reductive dechlorination is a biodegradation reaction in which a $\mathrm{CAH}$ is degraded by an enzyme or cofactor produced during microbial metabolism of another compound. Several anaerobic microbe species can reductively dechlorinate through cometabolic reactions, by transfer of electrons from the reduced cofactors. This enzymatic breakdown of the CAHs does not provide energy to the 
microbes for life processes and therefore is not as efficient as the actions of another type of anaerobic microbe group called dehalorespiring or chloro-respiring microbes. (Major et al $2001 \mathrm{p} 27$ ) The chloro-respiring microbes use chlorinated solvents as terminal electron acceptors and gain energy from reductive dechlorination to support their life processes. Of the chloro-respiring microbes, Dehalococcoides ethenogenes is able to dechlorinate chlorinated ethenes completely.

Aerobic oxidation is the process of microbial breakdown of a compound in which the compound serves as an electron donor and as a growth substrate for the microbe. The oxygen in the aerobic environment acts as the electron acceptor. Figure II-4 illustrates the reaction process for the aerobic oxidation of a CAH. (US EPA 2000 p 2-13)

Figure II-4. Aerobic Oxidation of a CAH

\begin{tabular}{|c|c|}
\hline $\mathrm{CAH}$ & Oxidized \\
${_{2}} \stackrel{\text { Aerobic microbe }}{\stackrel{\text { Reduced }}{\longrightarrow} \mathrm{CO}_{2}+\mathrm{H}_{2} \mathrm{O}+\mathrm{Cl}+\text { energy }} }$ & $\mathrm{H}_{2} \mathrm{O}$ \\
&
\end{tabular}

In general, only the less fully chlorinated CAHs such as DCE and VC can be oxidized under aerobic conditions. This fact presents a limit to use for this type of microbe since aerobic oxidation has no affect on the more chlorinated CAHs such PCE and TCE.

To solve this problem, the idea of using a cometabolite was developed. (US EPA 2000 p 2-14) Cometabolic aerobic oxidation is microbial breakdown of a 
compound in which the compound is oxidized incidentally by a cofactor or enzyme produced during the microbial metabolism of another compound. Figure II-5 illustrates the reaction process for cometabolic aerobic oxidation of a $\mathrm{CAH}$ using toluene as the cometabolite.

Figure II-5. Cometabolic Aerobic Oxidation of a CAH

Toluene $\longrightarrow \mathrm{CO}_{2}+\mathrm{H}_{2} \mathrm{O}+$ energy

$\mathrm{CAH} \longrightarrow$ Aerobic Microbe $\longrightarrow$ Epoxide $\longrightarrow$ Alcohols + Organic Acids

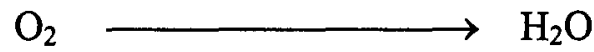

Several studies (US EPA 2000 p 2-17) have suggested that the most efficient remediation of CAHs using microbes occurs where the aquifer is anaerobic in the upgradient zone and aerobic in the downgradient zone. Cometabolites are not necessary in this situation since anaerobic microbes from the upgradient zone will reduce PCE and TCE to DCE and VC. Then the DCE and VC resulting from the anaerobic reduction move with the groundwater flow to the aerobic zone where they are oxidized to carbon dioxide, chlorine and water.

In general, the substrate requirement for cometabolism is much greater than that required for direct metabolism. Typically, for the cometabolic process, the amount of primary substrate required is 100 to 1000 times than the amount of CAH. (US EPA 2000 p 2-17) 


\section{K. Bioremediation Technology Selection and Implementation}

The steps followed in selecting and implementing an in situ microbial remediation system at a site contaminated with CAHs are basically the same as for other remediation technologies except that special attention is given to identifying degradation mechanisms that exist at the site and enhancement technologies that could be applied.

Typical steps in selection and implementation are:

1. Evaluate site characteristics

2. Identify general site conditions

3. Identify primary reactants and possible additives

4. Perform treatability (laboratory scale) testing

5. Perform field design, field testing and implementation

Steps 1, 2 and 3 determine the selection of the technology to be confirmed by lab tests. Steps 4 and 5 determine the implementation of the technology.

\section{Site Characteristics}

The physical, chemical and biological parameters of the site must be determined in order to select and design the appropriate technology. (US EPA 2000 p 4-1)

The physical parameters determine how and at what rates gases and liquids move through the soils, aquifers and other geologic units. Physical parameters include porosity, hydraulic conductivity and hydraulic gradient of the various geologic units and the organic and moisture contents of the soil. 
The chemical and biological parameters determine what type of degradation mechanism is possible and the rate of degradation.

The chemical parameters include: concentrations of $\mathrm{CAHs}$ and daughter products; oxygen content; $\mathrm{pH}$; redox potential; concentrations of electron donors and acceptors; and nutrient concentrations. These parameters determine if the site is aerobic or anaerobic, whether sufficient electron acceptors or donors are present to support biodegradation and how much intrinsic biodegradation is already occurring at the site.

The CAH concentrations can affect the degradation mechanisms that may be occurring as well as substrate levels for direct degradation. The presence of contaminants such as toluene, methane or phenol may augment performance by providing a substrate for depleting oxygen or a substrate for cometabolic degradation. High levels of toxic compounds or metals could inhibit microbial activity: The daughter product concentrations and distributions can indicate whether or not microbial degradation is already taking place.

The dissolved hydrogen concentration can indicate what type of terminal electron accepting process is occurring. Table II- 1 shows the relationship between hydrogen concentration and terminal electron accepting process. The terminal electron accepting process is used in determining what types of microbes are present at the site.

Table II-1. Terminal Electron Accepting Process Related to Hydrogen Concentration (US EPA 2000 p 4-5)

\begin{tabular}{|c|c|}
\hline Terminal Electron Accepting Process & Hydrogen Concentration (nanomoles/L) \\
\hline Denitrification & $<0.1$ \\
\hline Iron (III) reduction & 0.2 to 0.8 \\
\hline Sulfate reduction & 1 to 4 \\
\hline Reductive dechlorination & $>1$ \\
\hline Methanogenisis & 5 to 20 \\
\hline
\end{tabular}


The redox potential is used to determine if the site conditions will promote oxidation or reduction.

The biological parameters include the presence of specific and non-specific microbes and microbial activity. The presence and concentration of non-specific microbes is measured as total organic carbon and is used to estimate the quantity of microbes at the site. The presence and concentration of specific microbes can be used to determine the concentration of the target microbe at the site. Microbial activity is measured by oxygen uptake rate or dehydrogenate activity. The uptake rate is used to quantify the rate of activity of the target microbe. (US EPA $2000 \mathrm{p} \mathrm{4-1,2}$ and 5)

\section{Site Conditions}

Data on hydrogeologic and aquifer chemistry can determine if the site conditions are favorable for microbial remediation. Table II-2 lists the favorable and unfavorable hydrogeologic and aquifer chemistry conditions. (US EPA $2000 \mathrm{p} 4-6$ ) Possible engineered solutions for the unfavorable conditions are also listed. 
Table II-2. Favorable and Unfavorable Site Conditions for Microbial Remediation of CAHs and Engineered Solutions for Unfavorable Conditions

(US EPA $2000 \mathrm{p} \mathrm{4-6)}$

\begin{tabular}{|c|c|c|}
\hline \multicolumn{2}{|c|}{ Conditions } & \multirow{2}{*}{$\begin{array}{l}\text { Engineered Solution } \\
\text { for Unfavorable } \\
\text { Conditions }\end{array}$} \\
\hline Favorable & Unfavorable & \\
\hline \multicolumn{3}{|c|}{ Hydrogeologic } \\
\hline Granular porous media & Fractured rock & na \\
\hline $\begin{array}{l}\text { High permeability } \\
\left(\mathrm{K}>10^{-4} \mathrm{~cm} / \mathrm{s}\right)\end{array}$ & $\begin{array}{l}\text { Low permeability } \\
\left(\mathrm{K}<10^{-4} \mathrm{~cm} / \mathrm{s}\right)\end{array}$ & $\begin{array}{l}\text { Hydro and pneumatic } \\
\text { fracturing }\end{array}$ \\
\hline Saturated media & Unsaturated media & Water application \\
\hline Minimal heterogeneity & Highly stratified deposits & na \\
\hline \multicolumn{3}{|c|}{ Aquifer Chemistry } \\
\hline $\begin{array}{l}\text { Minimal NAPL in } \\
\text { target area }\end{array}$ & $\begin{array}{l}\text { Significant NAPL in } \\
\text { target area }\end{array}$ & $\begin{array}{l}\text { Source contaminant } \\
\text { treatment, or removal }\end{array}$ \\
\hline $\mathrm{pH}$ between 6 and 8 & pH extremes & $\begin{array}{l}\text { Chemical additives } \\
\left(\mathrm{NaHCO}_{3} \text { as a buffer }\right)\end{array}$ \\
\hline $\begin{array}{l}\text { Nontoxic contaminant } \\
\text { concentrations }\end{array}$ & $\begin{array}{l}\text { Toxic contaminant } \\
\text { concentrations }\end{array}$ & $\begin{array}{l}\text { Dilution by injection of } \\
\text { water or } \\
\text { bioremediation } \\
\text { additives }\end{array}$ \\
\hline $\begin{array}{l}\text { Simple contaminant } \\
\text { mixtures }\end{array}$ & $\begin{array}{l}\text { Complex contaminant } \\
\text { mixtures }\end{array}$ & na \\
\hline $\begin{array}{l}\text { Moderate to high } \\
\text { microbial activity of } \\
\text { appropriate microbes }\end{array}$ & $\begin{array}{l}\text { Little microbial activity or } \\
\text { inappropriate microbes }\end{array}$ & Bioaugmentation \\
\hline $\begin{array}{l}\text { Sufficient nutrients } \\
\text { present }\end{array}$ & $\begin{array}{l}\text { Insufficient nutrients } \\
\text { present }\end{array}$ & Addition of nutrients \\
\hline $\begin{array}{l}\text { Sufficient primary } \\
\text { reactants }\end{array}$ & $\begin{array}{l}\text { Insufficient primary } \\
\text { reactants }\end{array}$ & $\begin{array}{l}\text { Add reactants needed } \\
\text { to employ specific } \\
\text { mechanism }\end{array}$ \\
\hline
\end{tabular}

\section{Primary Reactants and Possible Additives}

The type of reactants and additives typically used in microbial remediation vary by mechanism (such as direct and cometabolic aerobic oxidation, and anaerobic reductive dechlorination) and also vary by targeted CAHs. (US EPA $2000 \mathrm{p} 4-7$ )Table 
II-3 shows the different combinations of these variations (only includes CAHs mentioned in this paper).

Table II-3. Primary Reactants and Additives for Microbial Engineered Systems (US EPA $2000 \mathrm{p} 4-7$ )

\begin{tabular}{|l|l|l|l|}
\hline $\begin{array}{l}\text { Engineered } \\
\text { Bioremediation } \\
\text { Mechanism }\end{array}$ & \multirow{2}{*}{$\begin{array}{l}\text { Targeted } \\
\text { CAHs }\end{array}$} & \multicolumn{2}{|l|}{$\begin{array}{l}\text { Primary Reactants and Additives for } \\
\text { Microbial Engineered Systems }\end{array}$} \\
\cline { 3 - 4 } & & Primary Reactants & $\begin{array}{l}\text { Additives (primary } \\
\text { reactant supplemented) }\end{array}$ \\
\hline $\begin{array}{l}\text { Aerobic oxidation } \\
\text { (direct) }\end{array}$ & DCE, VC & Oxygen, CAH & $\begin{array}{l}\text { Air, oxygen, hydrogen } \\
\text { peroxide, magnesium } \\
\text { peroxide (oxygen) }\end{array}$ \\
\hline $\begin{array}{l}\text { Aerobic oxidation } \\
\text { (co metabolic) }\end{array}$ & $\begin{array}{l}\text { TCE, DCE, } \\
\text { VC }\end{array}$ & Oxygen & $\begin{array}{l}\text { Air, oxygen, hydrogen } \\
\text { peroxide, magnesium } \\
\text { peroxide (oxygen) }\end{array}$ \\
\hline $\begin{array}{l}\text { Anaerobic } \\
\text { reductive } \\
\text { dechlorination }\end{array}$ & $\begin{array}{l}\text { PCE, TCE, } \\
\text { DCE, VC }\end{array}$ & $\begin{array}{l}\text { Hydrogen, organic } \\
\text { carbon, or carbon } \\
\text { from contaminant } \\
\text { source }\end{array}$ & $\begin{array}{l}\text { Lactate, methanol, } \\
\text { hydrogen, molasses } \\
\text { (electron donor) }\end{array}$ \\
\hline
\end{tabular}

Treatability (Laboratory Scale) Testing

Treatability (laboratory scale) testing can proceed after site characteristics, degradation mechanisms, and potential enhancements are identified. Lab tests are conducted to evaluate the effectiveness of the degradation mechanisms and enhancements that are being considered for implementation at the site. Tests are conducted utilizing samples from several areas of the site because microbe populations are usually heterogeneous and conditions in a plume may vary across the site. It should be noted that degradation rates observed in the lab are typically higher than those found in the field. (US EPA $2000 \mathrm{p}$ 4-7) 
The information derived from the first four steps in selecting and implementing an in situ microbial remediation system is used in designing the system, testing the system in the field and implementing the technology on a fullscale cleanup.

In previous sections, the potential for using microbes as a remediation technology for TCE has been described. Microbes also can be utilized for treatment of other contaminants. Heavy metals such as Tc-99 can be immobilized by a special group of microbes termed extremophiles.

\section{Extremophiles}

Extremophiles are microbes that can survive in the most inhospitable environments. Some of these microbes can withstand large doses of radiation; that fact led to research on using them for radioactive waste cleanup. (Fialka Nov. 16, 2004)

The mobility of the radionuclides technetium (Tc-99) and uranium (U) in groundwater depends on site-specific biogeochemical conditions. In oxidizing environments, Tc-99 occurs as Tc(VII) in the form of a highly soluble and mobile pertechnetate anion $\left(\mathrm{TcO}_{4}{ }^{-}\right)$and $\mathrm{U}$ occurs as $\mathrm{U}(\mathrm{VI})$ which forms highly soluble and mobile complexes with carbonate at $\mathrm{pH}>5$. In reducing environments, $\mathrm{Tc}$ occurs as $\mathrm{Tc}(\mathrm{IV}$ and $\mathrm{V})$ and $\mathrm{U}$ occurs as $\mathrm{U}(\mathrm{IV})$, which have much lower solubility and much less mobility than their oxidized forms. 
The concept of bio-immobilization has been proposed as a strategy for reducing Tc and U concentrations in groundwater. (Istok et al $2004 \mathrm{p} \mathrm{468)} \mathrm{Bio-}$ immobilization is the addition of nutrients to stimulate indigenous microbes (extremophiles) to reduce $\mathrm{Tc}(\mathrm{VII})$ and $\mathrm{U}(\mathrm{VI})$ to produce and precipitate $\mathrm{Tc}(\mathrm{IV}$ and $\mathrm{V}$ ) and U(IV) solid phases.

For aerobic conditions, the addition of an electron donor is necessary to produce the anaerobic and reducing conditions required for the growth of these extremophile metal reducing microbes. This approach may be complicated because of the presence of high concentrations of nitrate $\left(\mathrm{NO}_{3}{ }^{-}\right)$from ore processing and isotope separation processes that took place at contaminated sites such as PGDP. $\mathrm{NO}_{3}{ }^{-}$serves as a competing and more favorable electron acceptor, and must be removed to maintain reducing conditions.

Other concerns with reducing $\mathrm{Tc}$ and $\mathrm{U}$ to their precipitate form is the restriction of flow in the aquifer caused by the immobile precipitates, and the possibility of the precipitates to reoxidize and become mobile again from changes in the aquifer environment. (Luo April 25, 2004)

\section{L. $\underline{\text { Humic Products }}$}

The term "humic" refers to a type of decomposed organic matter such as compost to be used in contaminated soil and groundwater remediation. Scientists of the Newly Independent States (NIS) of the former Soviet Union developed a humic product called Humosorb to be used as a soil amendment to immobilize heavy metals and prevent their uptake into plants. (CRADA 1998 p 2) 
Another humic product called HMA has been covered by an application for a patent according to Dave McEwan of the AST Companies. Lab studies have shown HMA is capable of reducing polychlorinated biphenyls (PCBs) in soil. Field studies show HMA is capable of immobilizing a variety of heavy metals. The results of these studies are described in appendix B.

In a personal communication (Shulgin, July 1, 2005), Dr. Alexander Shulgin, a NIS scientist, described the benefits of HMA. TCE remediation can be accomplished by mechanisms similar to those featured in PCB remediation using HMA. HMA can be used as a substrate and nutrient to enhance bioremediation of TCE. HMA as a nutrient can foster diversity in microbe species to allow remediation of a variety of contaminants.

\section{Nanotechnology}

Researchers at Lehigh University recently discovered that nanoscale (1 to $100 \mathrm{~nm}$ ) iron particles can play a large role in remediation of contaminated groundwater. (Zhang $2003 \mathrm{p} 323$ ) The advantage of the small size is that it increases the specific surface of the iron so that the iron is more effective, and the iron can be transported more easily through the groundwater. A slurry of nanoparticles of iron in water can be injected into a contaminated plume by gravity flow or under pressure. Once in the plume, the nanoparticles can stay in suspension for long periods of time to create an in situ treatment zone. The nanoscale iron can treat chlorinated organic compounds such as TCE by reductive dechlorination. By the same process, nanoscale 
iron particles have the potential to immobilize heavy metals and radionuclides such as Tc-99. (Zhang 2003 p 324)

Zero-valent iron $\left(\mathrm{Fe}^{0}\right)$ can react with dissolved oxygen and, to some extent, with water. The following reactions represent electrochemical corrosion where iron is oxidized from exposure to water and oxygen.

$$
\begin{aligned}
& 2 \mathrm{Fe}^{0}{ }_{(\mathrm{s})}+4 \mathrm{H}^{+}{ }_{(\mathrm{aq})}+\mathrm{O}_{2(\mathrm{aq})} \rightarrow 2 \mathrm{Fe}^{2+}{ }_{(\mathrm{aq})}+2 \mathrm{H}_{2} \mathrm{O}_{(\mathrm{l})} \\
& \mathrm{Fe}^{0}{ }_{(\mathrm{s})}+2 \mathrm{H}_{2} \mathrm{O}_{(\mathrm{l})} \rightarrow 2 \mathrm{Fe}^{2+}{ }_{(\mathrm{aq})}+\mathrm{H}_{2(\mathrm{~g})}+2 \mathrm{OH}^{-}{ }_{(\mathrm{aq})}
\end{aligned}
$$

Chlorinated solvents such as tetrachloroethylene $\left(\mathrm{C}_{2} \mathrm{Cl}_{4}\right)$ can readily accept electrons from the iron oxidation and be reduced to ethylene as shown in the following reaction. (Zhang 2003 p 325)

$$
\mathrm{C}_{2} \mathrm{Cl}_{4}+4 \mathrm{Fe}^{0}+4 \mathrm{H}^{+} \rightarrow \mathrm{C}_{2} \mathrm{H}_{4}+4 \mathrm{Fe}^{2+}+4 \mathrm{Cl}^{-}
$$

Environmental applications of zero-valent iron have been accepted by users and regulators because of low cost and lack of known toxic effects induced by the use of iron. Zero-valent iron has been used in the form of packed bed reactors and in permeable reactive barriers. (Zhang 2003 p 325)

The pertinent water chemistry in the iron-mediated reactions produce 1) an increase in $\mathrm{pH}$, and 2) a decrease in redox potential. A highly reducing environment is developed from the consumption of oxygen and the production of hydrogen. This effect should favor the growth of anaerobic microbes which could be beneficial to biodegradation. 


\section{N. Permeable Reactive Barriers}

Permeable reactive barriers (PRBs), also known as in situ reactive wall groundwater treatment systems, or passive reactive barrier systems, utilize an existing hydraulic gradient to cause groundwater to pass through a treatment medium, yielding a passive treatment system. The advantage of PRBs is the reduced operating and maintenance cost since there are no pumps and processing equipment to operate and maintain. Monitoring is typically the only operating cost encountered with PRBs. (Andromalos 2005)

The term "barrier" in the PRB name refers to a barrier for the contaminants, but not for the groundwater. The PRB should be designed to be more permeable than the surrounding aquifer so the water can flow through the barrier freely, leaving the contaminants in the barrier. Figure II-5 illustrates the basic dimensions used to describe a PRB.

\section{Figure II-6 Dimensions of a Permeable Reactive Barrier (ITRC Feb 2005 p 3)}

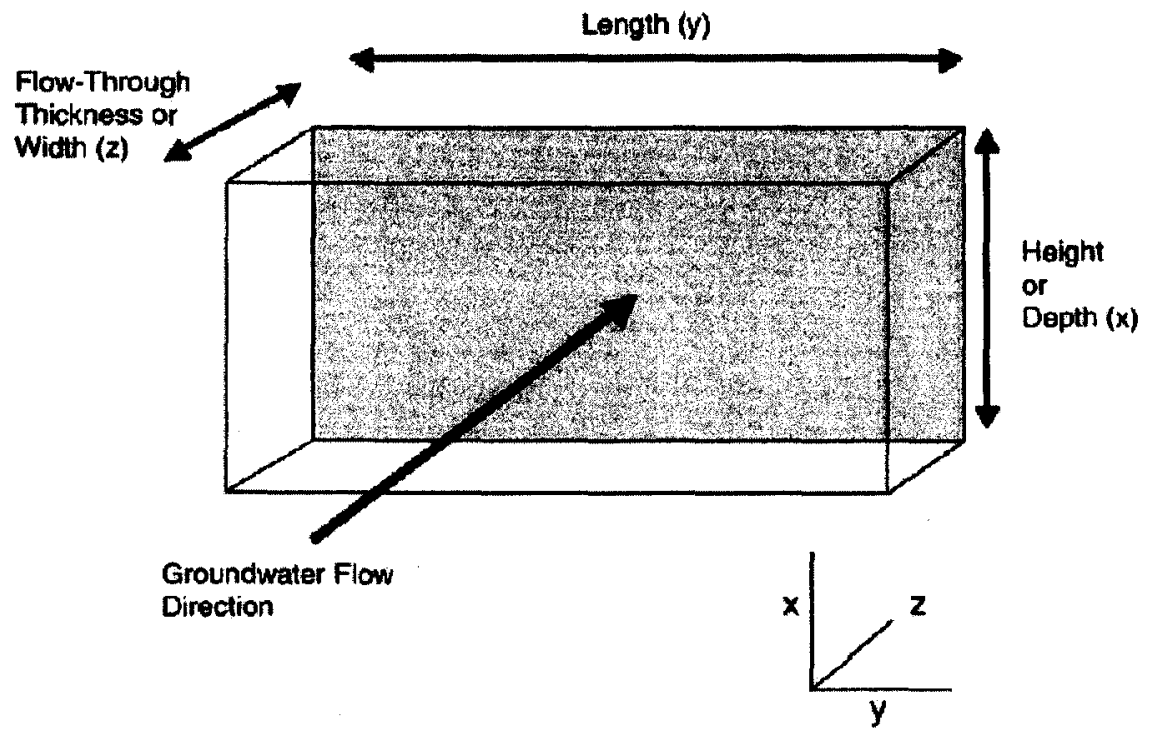

PRBs typically are used as on-site containments or as a source management remedy. Different site specific objectives determine the PRB design. A PRB could be 
installed near a downgradient site boundary to prevent further migration of a contaminant plume. A PRB installed near the downgradient side of the source could be used to reduce the high contaminant levels to a lower percent concentration that can be treated by natural attenuation or some other remedy, to address the residual contamination downgradient from the PRB. (ITRC Feb 2005 p 2)

\section{Alternative Systems}

PRB systems can be separated into four general categories: continuous wall; funnel and gate; passive collection with treatment reactor cells; and injection well barriers. Examples of the various types of PRBs are shown in Figure II-6.

Figure II-7 Examples of various types of PRBs (ITRC Feb 2005 p 3)

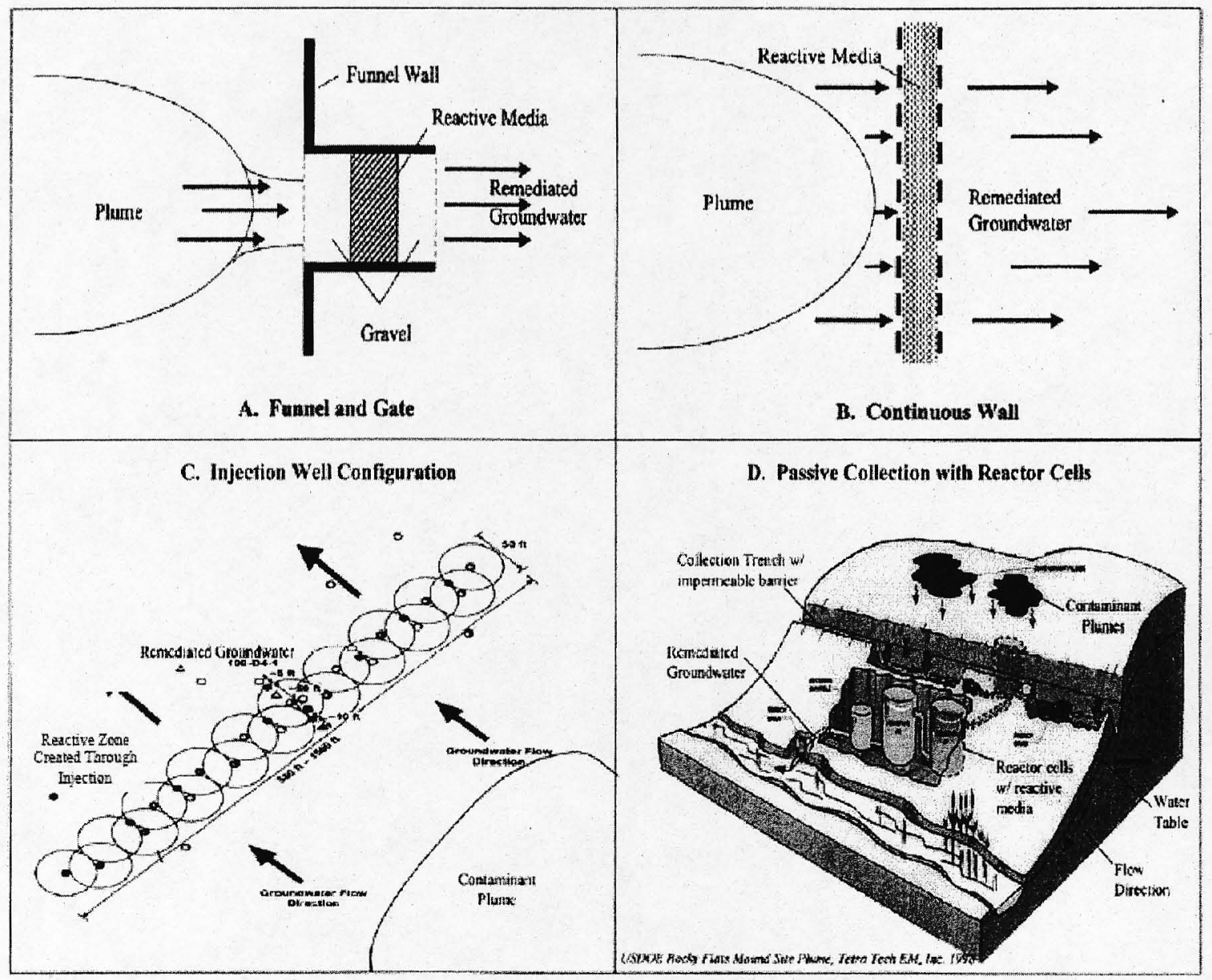


The funnel and gate system consists of vertical groundwater barriers arranged as a "funnel" to direct groundwater flow through a PRB section or "gate" for treatment. The funnel portion can be constructed in a variety of configurations such as slurry walls, steel sheet pilings with grouted interlocks, and high density polyethylene (HDPE) composite walls. The slurry walls used for the funnel walls include soil-bentonite and soil-cement-bentonite combinations.

Continuous wall PRBs consist of treatment media installed as continuous walls perpendicular to the groundwater flow direction. The treatment media can be installed by a variety of methods such as traditional excavation and backfill techniques, caisson drilling, one-pass trenching machines, biopolymer slurry trenching techniques, deep soil mixing, high-pressure jetting and hydraulic fracturing techniques.

Injection well barrier PRB systems use a line of injection wells to inject treatment media to create a reactive zone. The treatment media typically used with this system would be nutrients to create a biofilm barrier, or oxygen-releasing and hydrogen-releasing compounds to accommodate biodegradation of the contaminants.

Passive collection with treatment reactors is a PRB system that uses a series of underground treatment reactors instead of the reactive gates used in the funnel and gate system. The reactors can be arranged in series or in parallel to allow for changing the treatment media while the system is active.

\section{Treatment Media}

The treatment media successfully used in PRB systems to date (2005) include zero-valent iron, limestone, activated carbon, a variety of biological nutrients, and various hydrogen-releasing and oxygen-releasing compounds. Zero-valent iron has 
been the most widely used treatment medium in full-scale PRBs to date. (ITRC Feb $2005 \mathrm{p} \mathrm{1)} \mathrm{The} \mathrm{prevalent} \mathrm{use} \mathrm{of} \mathrm{zero-valent} \mathrm{iron} \mathrm{results} \mathrm{from} \mathrm{its} \mathrm{ability} \mathrm{to} \mathrm{degrade} \mathrm{a}$ variety of contaminants, the most common of which are chlorinated solvents such as PCE and TCE. Zero-valent iron degrades PCE and TCE by the abiotic reductive dehalogenation process described in the nanotechnology section of this chapter.

For PRB systems that include passive collection with treatment reactors, activated carbon typically is used as the treatment medium. Activated carbon can remove a variety of contaminants but must be replenished with extended use.

Limestone gravel is used as the treatment medium when an increase in $\mathrm{pH}$ is needed. An increase in $\mathrm{pH}$ can help immobilize metals that are dissolved in the groundwater or make the appropriate $\mathrm{pH}$ adjustment in an acidic environment.

The key elements involved in oxidation-reduction reactions used to degrade contaminants include carbon, nitrogen, sulfur, iron, and manganese. The proper balance of these elements in an aqueous system can ensure that the oxidation-reduction reactions will control the fate of the contaminant. Modification of the redox sensitive elements combined with $\mathrm{pH}$ adjustment can be an effective goal of PRB based remediation. Based on the ability to manipulate the redox condition of an aquifer, a new class of redox enhanced PRBs evolved. (ITRC Feb 2005 p 12) The use of these PRBs appropriately has been called an "in situ redox manipulation" process. Treatment media applied to PRBs in order to promote remediation through oxidation-reduction control include iron, compost, sodium dithionate, hydrogen sulfide, acetate, and a variety of carbohydrates. 
Materials in the groundwater remediation industry that promote sorption reactions typically have not been associated with PRBs. These materials have been used in groundwater remediation to limit the migration or removal of contaminants and increasingly are being applied to PRB systems. For effective sorption in PRBs, the materials must be relatively hydrophobic, insoluble and easy to apply. (ITRC Feb 2005 p 13) Treatment media applied to PRBs in order to promote remediation through sorption include granular activated carbon, bone char, phosphatic compounds (includes apatite and enhanced apatite), zeolites, coal, peat, synthetic resins, solid carbon sources (compost, peat, sawdust, wood chips, wheat straw and cheese whey), recycled carbonrich materials (foundry byproducts, tire chips, and paper sludges) and green waste sands. (ITRC Feb 2005 p 13)

Biological enhancements are another category of treatment media that can be applied to PRBs. Biological processes, despite involving multiple steps to reduce or destroy a contaminant, can be effectively used in a remediation strategy in a PRB environment. The benefits of biological PRBs is that the treatment process can extend beyond the installed treatment zone and a single system can treat multiple contaminants having different chemical characteristics. Treatment media applied to PRBs in order to promote remediation through a biological process include solid oxygen-releasing and hydrogen-releasing compounds, oxygen and hydrogen sources in gas emitters, solid and liquid carbon sources (saw dust, wheat straw, cheese whey, vanilla, sucrose, and other carbohydrates), different compositions of compost, pecan shells and granular activated carbon. (ITRC Feb 2005 p14) A partial list of treatment media that can be used in PRBs is given in Table II-4. 
Table II-4 PRB treatment media for different treatment methods

(ITRC Feb 2005 p 14)

\begin{tabular}{|l|l|l|}
\hline \multicolumn{1}{|c|}{ PRB Treatment } & \multicolumn{1}{|c|}{ Treatment Media } & \multicolumn{1}{c|}{ Contaminants Treated } \\
\hline $\begin{array}{l}\text { Metal enhanced } \\
\text { reductive dechlorination } \\
\text { of organic compounds }\end{array}$ & Zero-valent metals (iron) & $\begin{array}{l}\text { Chlorinated ethenes, } \\
\text { ethanes, methanes, } \\
\text { propanes, chlorinated } \\
\text { pesticides, freons, } \\
\text { nitrobenzene }\end{array}$ \\
\hline $\begin{array}{l}\text { Sorption and ion } \\
\text { exchange }\end{array}$ & $\begin{array}{l}\text { Zero-valent iron, granular } \\
\text { activated carbon, apatite, } \\
\text { bone char, zeolites, peat, } \\
\text { humate }\end{array}$ & $\begin{array}{l}\text { Some chlorinated solvents, } \\
\text { BTEX, Sr-90, Tc-99, U, } \\
\text { Mo }\end{array}$ \\
\hline pH control & Limestone, zero-valent iron & Cr, Mo, U, acidic water \\
\hline $\begin{array}{l}\text { In situ redox } \\
\text { manipulation }\end{array}$ & $\begin{array}{l}\text { Sodium dithionite, calcium } \\
\text { polysulfide }\end{array}$ & Cr, chlorinated ethenes \\
\hline $\begin{array}{l}\text { Enhancement for } \\
\text { bioremediation }\end{array}$ & $\begin{array}{l}\text { Oxygen release compounds, } \\
\text { hydrogen release } \\
\text { compounds, carbohydrates, } \\
\text { lactate, zero-valent iron, } \\
\text { compost, peat, sawdust, } \\
\text { acetate, humate }\end{array}$ & $\begin{array}{l}\text { Chlorinated ethenes and } \\
\text { ethanes, nitrate, sulfate, } \\
\text { perchlorate, Cr, MTBE, } \\
\text { polyaromatic } \\
\text { hydrocarbons }\end{array}$ \\
\hline
\end{tabular}




\section{TECHNOLOGY PERFORMANCE}

The previous chapter provided a detailed description of the remediation technologies being considered for use at the PGDP and indicated the site conditions to assess in order to evaluate the feasibility of implementing the technology. This chapter summarizes recent full-scale and pilot studies of the technologies under consideration. Vendor information is given for newer technologies and technologies lacking current case studies. Site conditions and contamination scenarios similar to those at the PGDP site were the primary criteria for selection in the search for case studies. The purpose of the case studies is to compare values of critical factors for each technology as given in the case documentation. The factors considered by the TAG included: implementation cost and ease of implementation; technology maturity and appropriateness; life-cycle costs and overall cost-effectiveness; ability to reduce the contaminants to regulatory levels of compliance; compatibility with existing site constraints and treatment systems; stakeholder considerations; and regulatory permits. The cost represented in the following case studies is the cost at the time that the technology was implemented for that study. A summary of values for these factors, based on these case studies, is given 
in Chapter IV for the relevant technologies. The cost in the Chapter IV summary will be estimated at a value for the year 2005 .

\section{A. Rotary Treatment}

Rotary treatment case studies more recent than the ITRD1999 data were not available. The vendor used in the cost and performance estimates for rotary treatment was In-situ Fixation. A personal communication was made on June 22, 2005 with Collin Murdoch, the representative for In-situ Fixation. Mr. Murdoch confirmed that the 1999 ITRD data on performance could be used for updated performance data, and cost should increase in proportion to inflation.

\section{B. Soil Fracturing}

A field demonstration of hydraulic fracturing was conducted at the Portsmouth Gaseous Diffusion Plant in Piketon, Ohio. The demonstration compared the effects of fracturing on four different remediation technologies in the same soil conditions. The technologies compared were: steam injection; hot air injection; iron metal PRB and; chemical oxidation using potassium permanganate. The tests were conducted in silty clay soil where the depth to groundwater is typically 11.5 feet below ground surface. The soil water content was near saturation almost to the ground surface.

The dimensions of the four test cells were 45 feet by 45 feet in plan at a depth of 16 feet. The four test cells were categorized as: Cell A - Steam injection; Cell B - Hot air injection; Cell C - iron metal PRB; and Cell D - permanganate. The contaminant was TCE at a concentration of $100 \mathrm{mg} / \mathrm{kg}$. Four to five fractures were created in each 
cell at depths 4 to 18 feet below ground surface and spaced two to three feet apart. Cells A and B were operated 60 days in fall 1996 and 45 days in summer 1997. Cells C and D were operated passively during a two-year period.

The results from Cell A showed no significant improvement in steam injection remediation when combined with fracturing. Cell B showed that fracturing with hot air injection increased the rate of contaminant removal by volatilization. Cell $\mathrm{C}$ showed that the iron remained active ( 30 to 40 percent initial degradation of TCE) for up to 27 months after placement. Cell $\mathrm{D}$ showed that the permanganate was more active than in the situation without fractures, degrading more than 99 percent of the TCE in two hours. The costs for sand-propped fractures generally ranged from $\$ 850$ to $\$ 1,500$ per fracture. (US EPA $2001 \mathrm{p} 18$ )

\section{Chemical Oxidation with Ozone}

C-Sparge with ozone injection was implemented June 1, 2002 at the former Market Place Shopping Center in Hilton Head, South Carolina. At the former facility, Dryclean USA, located in the shopping center, perchloroethene (PCE) was used in the cleaning operation. The contaminants present and the highest amount detected in the groundwater, in ppb, were: 13,000 PCE; 5600 TCE; 6300 DCE; and 44 VC. The size of the contaminant plume was 250 feet by 200 feet with a depth of 45 feet.

As of October 21, 2004 the contaminant concentrations were reduced in ppb to: 146 PCE; 33.6 TCE; and 77.1 DCE; and VC was not detected. The cost for site assessment was $\$ 160,000$. The cost to design and implement the project was $\$ 311,000$. The cost for operation and maintenance was $\$ 50,000$. (SCRD $2005 \mathrm{p} 33$ ) 


\section{Chemical Oxidation with Permanganate}

Butler Cleaners, located in Jacksonville, Florida has been an active PCE

drycleaning site since 1972. The contaminants present and the highest amount detected in the groundwater in ppb were: 17,000 PCE; 830 TCE; 120 DCE; and 1,170 VC. The size of the treatment area was 10 feet by 40 feet with a depth of 30 feet.

The treatment consisted of three initial injection events of 5,000 gallons per injection of a $7.7 \mathrm{~g} / \mathrm{L}$ aqueous solution of potassium permanganate $\left(\mathrm{KMnO}_{4}\right)$. Periodic injections are ongoing.

Post-pilot test monitoring indicates that after permanganate injection, contaminant concentrations decreased in the treatment areas. Periodic monitoring indicates that rebound of elevated PCE concentrations occurs with the reduction of permanganate concentrations. The rebound of PCE concentrations likely occurs because of the residual DNAPL PCE that acts as a source of dissolved phase PCE.

The cost to design and implement the pilot test system was approximately $\$ 230,000$. The cost for quarterly monitoring and permanganate injection (not including reporting cost) was approximately $\$ 30,000$ per event. No time frame was given. The last profile update was on December 8, 2003. (SCRD 2005 p 9)

\section{E. Chemical Oxidation with the Fenton's Process}

The former Swift Cleaners was located in Jacksonville Beach, Florida where there is currently a parking lot for a Walgreens store. The contaminants present and the highest amount detected in the groundwater in ppb were: 21.5 PCE; 440 TCE; 1,400 
DCE; and $21 \mathrm{VC}$. The amounts in the soil in $\mu \mathrm{g} / \mathrm{kg}$ were: 530 PCE; $73 \mathrm{TCE}$; and 35

DCE. The size of the contaminant plume is an area of 1.6 acres at a depth of 40 feet.

Lab tests and a treatability study for chemical oxidation using Fenton's process were conducted in February 2002. Two chemical oxidation injections were implemented using Fenton's reagents on March 19-22, 2002 and April 23-24, 2002. There were 40 total injection points ( 20 clustered dual-zone). The reagents were injected 3 to 11 feet below ground surface and 11 to 17 feet below ground surface. Approximately 240 gallons of 12 percent hydrogen peroxide $\left(\mathrm{H}_{2} \mathrm{O}_{2}\right)$ and 120 gallons of catalyst were injected at each injection point.

The contaminant concentrations decreased considerably following the two injections. After two years of post-injection monitoring, the contaminant concentrations came back in range with the baseline-sampling event. The contaminant rebound is thought to have occurred because of the residual source that remained in the unsaturated zone. In June 2004, approximately 57 cubic yards of soil was removed from the source area in the unsaturated zone.

The cost for site assessment was $\$ 72,000$. The cost to design and implement the project was $\$ 9,300$ (remedial action plan), $\$ 10,000$ (lab test and treatability study), $\$ 117,000$ (two chemical oxidation injections) and $\$ 39,506$ (soil excavation). The cost for operation and maintenance was $\$ 7,700$ (annual monitoring). (SCRD 2005 p 12)

\section{F. Chemical Oxidation with Peroxide Activated Sodium Persulfate}

The peroxide activated sodium persulfate chemical oxidation process is referred to as CleanOX. The company that owns the patent to CleanOX is MECX. A chlorinated 
solvent manufacturing facility in St. Marys, Pennsylvania contracted MECX to conduct a series of two applications of CleanOX in order to remediate contamination under the floor of an existing production area. The first ten-day cycle took place in December 2002 and the second ten-day cycle in April 2003. The purpose of the two application cycles was to obtain a preliminary site characterization including a preliminary estimation of the total contaminant mass, and a lithology evaluation. The first application indicated that the actual site conditions had a contaminant mass approximately five times greater than the original estimate and a higher nonhomogeneous contaminant variance than anticipated.

The average contaminant concentration of the soil prior to the first application was $106,283 \mathrm{ppb}$. After the first application, the contaminant level dropped to 50,948 $\mathrm{ppb}$ and after the second application the contaminant level dropped to $7,172 \mathrm{ppb}$. The average contaminant concentration in the groundwater prior to the first application was $39,772 \mathrm{ppb}$. After the first application, the contaminant level dropped to $14,363 \mathrm{ppb}$ and after the second application the contaminant level dropped to 6,591 ppb.

The data show a 52 percent decrease in contaminant concentration in the soil and a 72 percent decrease in contaminant concentration in the groundwater after the first application. The data show a 93 percent decrease in contaminant concentration in the soil and an 83 percent decrease in contaminant concentration in the groundwater after the second application. Cost data was not available. (MECX 2005) 


\section{G. Soil Vapor Extraction}

The former Dollar Cleaners located in Lake Worth, Florida operated as a drycleaner using PCE for 19 months (1986-1987). The contaminants present and the highest amount detected in the groundwater in ppb were: 19.9 PCE; 27.4 TCE; and 66.3 DCE. The only information given on soil data was that the highest contaminant concentration detected in the soil was $190 \mu \mathrm{g} / \mathrm{kg}$ PCE. The size of the contaminant plume was 70 feet by 120 feet with a depth of 12 feet.

On December 13, 2001 six horizontal SVE wells were installed at the site under the slabs of the buildings. Four vertical and one horizontal passive vapor inlet wells were installed beneath the slabs. Three horizontal passive vapor inlet wells were located outside of the facility. Two 500-pound granular activated carbon vessels in series were used for emissions treatment.

The system operated until April 2002 (four months). Soil sampling showed that PCE in the soil had been reduced below cleanup target levels (less than $30 \mu \mathrm{g} / \mathrm{kg}$ ). No contaminants were detected in the groundwater at levels exceeding cleanup goals (less than $3 \mathrm{ppb}$ ). The cost for site assessment was $\$ 70,831$. The cost to design and implement the project was $\$ 134,598$. The cost for operation and maintenance was $\$ 29,910$. The cost for groundwater monitoring was $\$ 4,574$. The cost for closure and site restoration was $\$ 4,983$. The total cost for cleanup was $\$ 244,806$. (SCRD 2005 p 30)

\section{H. Six-Phase Heating}

A pilot study using Six-phase heating was conducted at PGDP near the southeast corner of the $\mathrm{C}-400$ building. The activities associated with the C-400 
building were cleaning machinery parts, disassembling and testing components; and laundering plant clothes. The two most significant sources of leaks and spills of VOCs have been identified at the southeast corner of the C-400 building. (US DOE $2003 \mathrm{p} \mathrm{1-}$ 3)

The six-phase array treatment area was 30 feet in diameter, heating a subsurface treatment area with a diameter of 43 feet. The electrodes reached a depth of 99 feet below ground surface. The SVE system maintained a slight vacuum and the vapor was drawn into granular activated carbon vessels. (US DOE 2003 p 1-7)

The treatability study began on February 14, 2003 and was scheduled to operate for 130 days. Because of positive TCE extraction and desire to increase the temperature at the base of the RGA, a 45-day extension was implemented. The heating was discontinued on September 6, 2003. The SVE continued for three more days to purge the treatment area of steam. (US DOE $2003 \mathrm{p} \mathrm{ix}$ )

The baseline soil sampling results indicated an average TCE concentration of $125,459 \mathrm{ppb}$, with a maximum concentration of $2,900,000 \mathrm{ppb}$. The average reduction of TCE in the soil was 98 percent. The average baseline groundwater concentration was $645,000 \mathrm{ppb}$. The average reduction of TCE in the groundwater was 99 percent. (US DOE 2003 p 2-1)

The estimated cost for the study was $\$ 6.3$ million. This cost included the installation of the system for which construction began in June 2002 and was completed in January 2003. (US DOE 2003 p 4-18) 
I. Steam: Dynamic Underground Stripping (DUS) and Hydrous Pyrolysis

\section{Oxidation (HPO)}

Steam (DUS/HPO) was used as a remediation technology in a field demonstration at the Savannah River Site 321-M Solvent Storage Tank Area in Aiken, South Carolina from September 9, 2000 to September 28, 2001. The contaminants were PCE and TCE introduced by leaks and spills from storage areas.

The three steam-injection well clusters were installed around the perimeter of the 100 foot by 100 foot treatment area. Each well cluster consisted of three injection wells with screened intervals at 50 to 70 feet, 110 to 130 feet, and 150 to 160 feet below ground surface. A dual-phase groundwater and vapor extraction well was installed in the center of the target zone with a screened interval from 20 to 160 feet below ground surface. The dual-phase well operated using a high temperature electricsubmersible pump, resistant to high temperatures, located at 143 feet below ground surface. Three vadose zone SVE wells were installed along the perimeter of the target zone. The steam for the system was supplied from other operations at the site. The extracted vapors were sent through a heat exchanger and a DNAPL-water separator. Air was injected into the deep saturated zone to enhance the HPO process.

Groundwater was heated to approximately $100^{\circ} \mathrm{C}$, while the soil in the source zone reached the same temperature.

The operation began September 9, 2000 and performance objectives were met by March 8, 2001. The system continued to operate until September 26, 2001 for additional contaminant removal. Specific values for treatment goals were not provided; 
however, by March 2001 it was reported that TCE levels were reduced by 62 percent and PCE levels were reduced by 26 percent.

The cost for the pilot project was $\$ 29$ per cubic yard not including steam generation and treatment of dissolved and vapor phase contaminants. The total volume of the treatment zone was approximately 59,000 cubic yards. (US EPA July 2003 p 28)

\section{J. Bioremediation}

\section{Anaerobic Microbes}

A natural microbial combination containing Dehalococcoides ethenogenes was used by the Remediation Technologies Development Forum (RTDF) in a field study at Dover Air Force Base in Delaware. Anaerobic microbe dechlorination had stalled at DCE, leaving an accumulation of DCE and VC despite continued electron donor addition. After bioaugmentation using the Dehalococcoides ethenogenes combination, complete dechlorination of DCE and VC to ethylene was observed. This discovery led to a full-scale study at Kelly Air Force Base in Texas. (Major et al 2001 p 27)

The study at Kelly Air Force Base utilized an indigenous anaerobic microbe with a natural non-pathogenic microbial combination referred to as KB-1. Geosyntec worked with the University of Toronto to isolate KB-1 to be used for bioaugmentation. The KB-1 combination utilizes strains of the Dehalococcoides ethenogenes microbe. A key component to this study was the ability to assess the absence of Dehalococcoides ethenogenes at the site before the remediation began and to track the spread of the KB1 strains of Dehalococcoides ethenogenes during the remediation. As in the field study 
in Delaware, the indigenous anaerobic microbe dechlorination had stalled at DCE, leaving an accumulation of DCE and VC. (Major et al 2001 p 28)

The field test consisted of a closed loop recirculation system, with three extraction wells, one injection well, and five biomonitoring wells. Figure III-1 shows the plan view of the system. The horizontal distance from the injection well to the extraction wells was 30 feet.

Figure III-1. Plan View of Test Area at Kelly Air Force Base (Major et al 2001 p 29)

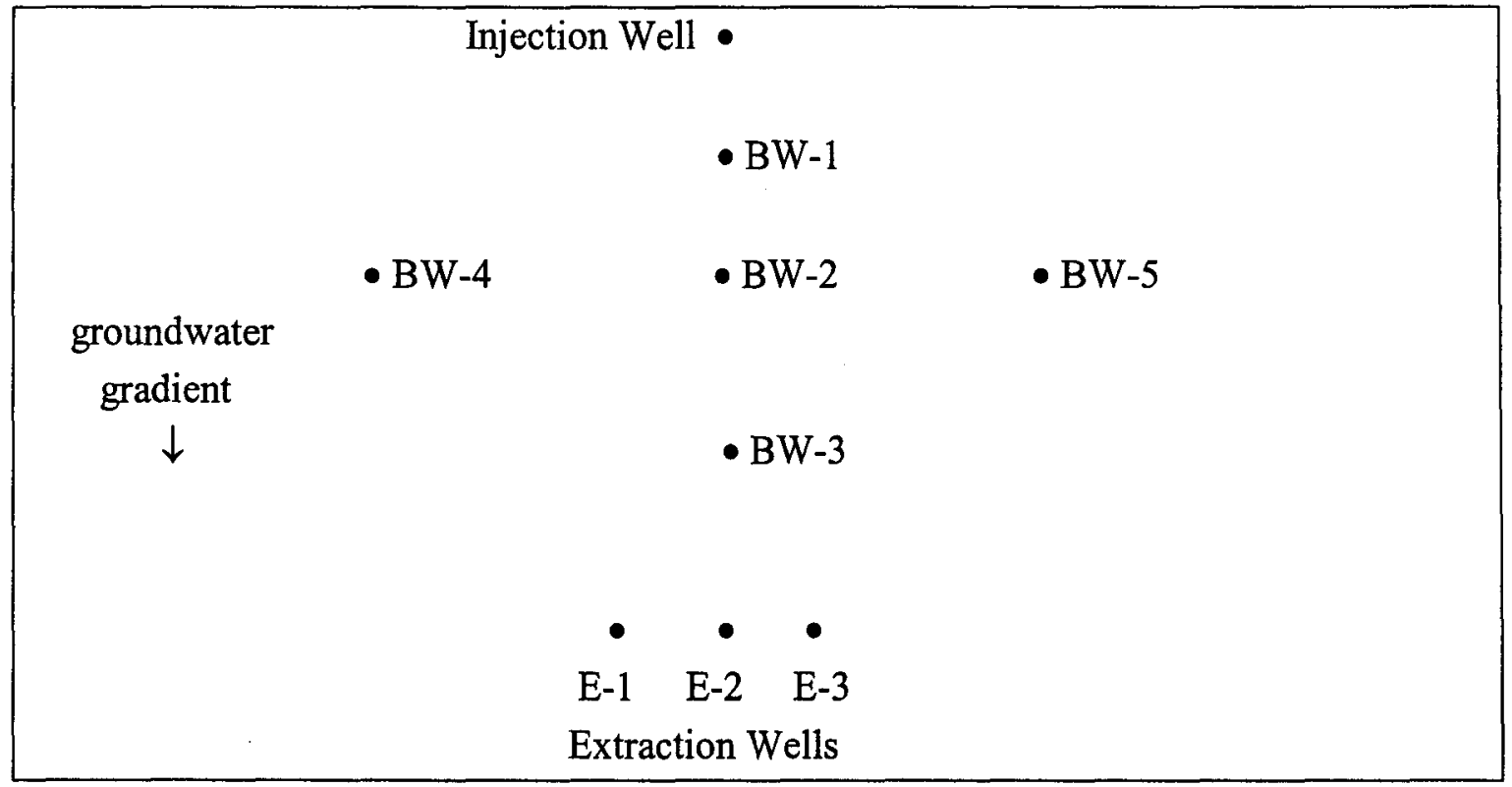

Electron donors (methanol/acetate) were injected into the groundwater at a rate to achieve desired concentrations based on the groundwater flow rate. After 87 days, all monitoring wells showed that PCE levels had decreased by more than $90 \%$ with the dominant degradation product being DCE. Before adding KB-1, soil and groundwater samples showed that Dehalococcoides ethenogenes was not detected. After 142 days of bioaugmentation with KB-1, ethylene was the dominant product in the test area. (Major et al $2001 \mathrm{p} \mathrm{31)}$ 
This field study demonstrated that indigenous microbes in the presence of electron donors could dechlorinate PCE reductively to DCE. Complete dechlorination was only observed after KB-1 was added to the aquifer. No cost data were provided with this study. (Major et al 2001 p 32)

\section{Anaerobic Microbes}

The Remediation Technologies Development Forum (RTDF) sponsored a field demonstration performed from May 1996 to March 1998 at the Dover AFB, Area 6 in Dover, Delaware using in situ bioremediation conducted in two phases. The first phase was stimulation of indigenous microbes for reductive dechlorination of TCE. In the second phase, a culture of microbes was imported from Largo, Florida to bioaugment the dechlorination process. The contaminants in the groundwater were $3 \mu \mathrm{g} / \mathrm{L} \mathrm{PCE}$, $4,800 \mu \mathrm{g} / \mathrm{L}$ TCE and $1,200 \mu \mathrm{g} / \mathrm{L}$ DCE.

Three injection wells and three extraction wells were aligned perpendicular to the groundwater flow with injection wells spaced 60 feet from extraction wells to create a recirculation area. During the first phase, sodium lactate was added on a seven-day cycle and the nutrients (ammonium phosphate and yeast extract) were pulse-fed. No reduction beyond DCE was observed during the first phase. During the second phase, after a lag period of 90 days, the imported culture began reducing DCE to VC and ethylene. Complete reduction of the chlorinated solvents to ethylene occurred by the end of the demonstration.

The estimated net 2005 value of the cost of the demonstration was $\$ 596,000$. (US EPA June 2002 p 42) 
The King of Cleaners in Orlando, Florida has been an active PCE drycleaning facility since 1987. The contaminants present and the highest amounts detected in the groundwater in ppb were: 390 PCE; 43.3 TCE; 73.8 DCE; and 7.8 VC. Only PCE was found in the soil, in a maximum concentration of $170 \mu \mathrm{g} / \mathrm{kg}$. The size of the contaminant plume was 300 feet by 140 feet at a depth of 40 feet.

Site assessment information led to the decision to use biostimulation to accelerate reductive dechlorination of the contaminants. On October 15, 2003, phase one was begun by injecting five gallons of 60 percent potassium lactate solution mixed with 1000 gallons of native water from one of the monitoring wells. Performance monitoring was conducted from November 2003 to January 2004, during which time little change in contaminant levels occurred. Phase two began on February 27, 2004, when an additional 50 gallons of 60 percent potassium lactate solution mixed with 2000 gallons of water were injected. Monitoring on March 26, 2004 showed PCE as undetected, TCE at $3.9 \mathrm{ppb}$ and DCE decreased to $51.1 \mathrm{ppb}$. Later post-remedial monitoring showed PCE and TCE as undetected, DCE levels dropped to a range of 40.8 to $20.6 \mathrm{ppb}$ and $\mathrm{VC}$ as undetected.

The cost for site assessment was $\$ 81,100$. The cost to design and implement the project was $\$ 37,800$. The cost for operation and maintenance was $\$ 45,400$ (six years of groundwater monitoring). The cost for site restoration was $\$ 4,200$. The total cost for cleanup was $\$ 168,500$. (SCRD 2005 p 158) 


\section{Aerobic Microbes}

The groundwater beneath the Savannah River Site Sanitary Landfill (SLF) in Aiken, South Carolina was contaminated primarily with TCE, DCE and VC. The SLF occupies a total area of 71 acres. A low-permeability geosynthetic cap was installed over 55 acres of the landfill to minimize infiltration and produce anaerobic conditions to facilitate reductive dechlorination of TCE. For the remaining uncapped 16 acres of the landfill, the site assessment warranted the use of a methanotropic (methane oxidizing) aerobic microbe using nitrous oxide and triethyl phosphate as nutrients.

The depth to groundwater ranged from 30 to 60 feet below ground surface in an unconfined aquifer consisting of interbedded sands and clayey/silty sands.

The biosparging system consisted of two horizontal wells, each with an injection pad, compressor and header; a nitrous oxide cylinder, a triethyl phosphate drum and methane vents that discharge directly into the air. The horizontal wells were installed 60 feet below ground surface, screened to lengths of 800 feet and 900 feet, respectively. The system was operated on a pulsed injection schedule. The groundwater monitoring network included 90 monitoring wells.

Initially, one well was used to inject methane, air and nutrients (nitrous oxide and triethyl phosphate) to stimulate the growth of the methanotropic microbes to degrade TCE. A second well injected air and nutrients to aerobically degrade DCE and VC.

Operations began in October 1999 and by January 2001 the TCE plume had diminished and methane injection was stopped. By February 2003, TCE levels were within compliance upgradient of the landfill and not detected at wells in the interior and 
downgradient of the landfill. VC concentrations continued to decrease over concentrations in the previous year and by February 2003 VC levels were reduced by 99 percent and TCE levels were reduced by 75 percent at wells in the interior and upgradient of the landfill and not detected at wells downgradient of the landfill.

The cost for installation of two horizontal injection wells was $\$ 1$ million. The cost for construction of injection pad and well piping was $\$ 750,000$. The cost for the operation of the biosparging system was $\$ 225,000$. The cost for groundwater monitoring was $\$ 215,000$ per year. (US EPA June $2004 \mathrm{p} 44$ )

\section{Extremophiles}

A field study at a DOE site in Oak Ridge, Tennessee provided a solution to this problem: A site with a combination of low $\mathrm{pH}$, and high and variable concentrations of $\mathrm{NO}_{3}^{-}, \mathrm{Tc}(\mathrm{VII})$, and $\mathrm{U}(\mathrm{VI})$ in an aerobic environment. These conditions are typical of DOE uranium mill tailing reclamation areas, and ore processing and isotope separation facilities. (Istok et al $2004 \mathrm{p} 469$ )

To monitor the response of the indigenous microbes to electron donor additions, single well push-pull tests and down-well microbial samplers were used. A series of injections of ethanol, acetate, or glucose was able to stimulate the growth and activity of the metal-reducing microbes. The results from this study showed that these microbes could successfully reduce $\mathrm{Tc}(\mathrm{VII})$ and $\mathrm{U}(\mathrm{VI})$ in this type of aquifer when the appropriate type and amount of electron donor is added. (Istok et al $2004 \mathrm{p} \mathrm{472)}$ 


\section{K. Nanotechnology}

A pilot study was conducted at the Naval Air Engineering Station (NAES) Site (Area 1) in Lakehurst, New Jersey using In Situ Bimetalic Nanoscale Particle (BNP) treatment to remediate VOC contaminated groundwater. The treatment zone encompasses an area approximately 300 square feet at a depth from 30 to 50 feet "below the water table". (US EPA June 2004 p 48) The contaminants consist of PCE, TCE, DCE and VC having a total VOC concentration of approximately $900 \mu \mathrm{g} / \mathrm{L}$. The BNP consist of nanoscale particles of zero valent iron with a trace coating of palladium ( 0.1 percent by weight) that acts as a catalyst.

Groundwater pumping was initiated one day prior to BNP injection to enhance in situ mixing and gain hydraulic control of the test area. BNP pressure injection was performed February 5 to 7, 2002 using three injection points. Groundwater monitoring was conducted on days $1,7,14$, and 28 following injection and samples were analyzed for VOCs, chloride, iron and geochemical parameters.

The results of the test were based on data collected from February 6 to May 6 of 2002. The total VOC reduction during this period was approximately 74 percent. Specific wells showed reductions as high as 100 percent for PCE, 74 percent for TCE, 89 percent for DCE and 88 percent for total VOCs. Reducing conditions were observed for two months after the pilot test. Based on the results, a larger scale pilot test was recommended. No cost was provided on this study. (US EPA June $2004 \mathrm{p} 48$ ) 


\section{Permeable Reactive Barriers}

At a former drycleaning site in an urban area in Westphalia, Germany a continuous-wall PRB was used for groundwater remediation. The contaminants present and the highest amounts detected in the groundwater in ppb were: 5,000 PCE; and 500 DCE. The size of the contaminant plume was 1,640 feet long and 820 feet wide in a loamy sand layer at 16 to 33 feet below ground surface. The hydraulic conductivity varied from 0.3 to $2.8 \mathrm{ft} /$ day and the water table was 10 feet below ground surface.

The continuous wall PRB was 74 feet long and approximately two and a half feet wide. The PRB was constructed by drilling a line of overlapping three footdiameter boreholes which were filled with reactive media up to the water table. The reactive media used in the wall were 69 tons of granular zero-valent iron mixed with gravel at a one to two volume ratio in 33 feet of the wall and 85 tons of iron sponge in the remaining 41 feet of wall. The iron sponge consists of wood chips permeated with iron oxide.

The effluent concentration of PCE was reduced to $500 \mathrm{ppb}$ from the granular iron section and reduced to $10 \mathrm{ppb}$ in the sponge section of the wall. No $\mathrm{VC}$ was observed. After four years of use, the sponge section was still increasing in degradation efficiency with the effluent PCE concentration less than $10 \mathrm{ppb}$. The degradation efficiency of the granular iron section was decreasing with the effluent PCE concentration increasing from $33 \mathrm{ppb}$ to $500 \mathrm{ppb}$. DCE and TCE were detected in the effluent from the granular iron section but no VC was detected. The research and development project was terminated in March 2004 after four years of monitoring. 
The cost to design and implement the project was $\$ 30,000$ for design and $\$ 93,000$ for reactive material and construction. The cost for operation and maintenance was $\$ 13,000$ for monitoring. (SCRD $2005 \mathrm{p} 31$ ) 


\section{SUMMARY OF TECHNOLOGY PERFORMANCE}

This chapter evaluates the case studies described in Chapter III for performance and cost. Table IV-1 lists the size of the treatment zone, contaminants, treatment period, percent contaminant reduction at the end of the treatment period, design and implementation cost, operation and maintenance cost, total cost and cost per cubic yard for each technology. The 1999 ITRD data were used for rotary treatment with a 17 percent increase in cost. The cost increase was based on the US Department of Labor Bureau of Labor Statistics CPI Inflation Calculator. This method was used to adjust the costs to 2005 dollars for all of the technologies. Table C-1 in the appendix gives the percent increase used for 1996 through 2004. Soil fracturing was not included in Table IV-1 because it is used to enhance other technologies. Recommendations on soil fracturing are given in Chapter V based on the case studies in Chapter III. Remediation methods using humic products were not listed in Table IV-1 since there were no case studies found using humic products. Recommendations on humic products are given in Chapter V. 
Table IV-1 Performance and Cost for Technology Case Studies

\begin{tabular}{|c|c|c|c|c|c|c|c|c|}
\hline Technology & $\begin{array}{c}\text { Size of } \\
\text { Treatment } \\
\text { Zone }\end{array}$ & $\begin{array}{c}\text { Contaminant } \\
\text { and } \\
\begin{array}{c}\text { Concentration } \\
\text { in ppb }\end{array} \\
\end{array}$ & $\begin{array}{c}\text { Percent } \\
\text { Contaminant } \\
\text { Reduction }\end{array}$ & $\begin{array}{l}\text { Treatment } \\
\text { Period }\end{array}$ & $\begin{array}{c}\text { Design and } \\
\text { Implementation } \\
\text { Cost }\end{array}$ & $\begin{array}{c}\text { Operation } \\
\text { and } \\
\text { Maintenance } \\
\text { Cost } \\
\end{array}$ & Total Cost & $\begin{array}{l}\text { Cost per } \\
\text { cubic yard }\end{array}$ \\
\hline $\begin{array}{c}\text { Rotary } \\
\text { Treatment }\end{array}$ & $10,000 \mathrm{yd}^{3}$ & $100,000 \mathrm{TCE}$ & $99.9 \mathrm{TCE}$ & $\begin{array}{c}2 \text { months } \\
250 \mathrm{yd}^{3} / \text { day }\end{array}$ & & & $\$ 643,500$ & $\$ 64.00$ \\
\hline $\begin{array}{l}\text { C-Sparge with } \\
\text { Ozone }\end{array}$ & $83,000 \mathrm{yd}^{3}$ & $\begin{array}{c}13,000 \text { PCE } \\
5,600 \text { TCE } \\
6,300 \text { DCE } \\
44 \text { VC }\end{array}$ & $\begin{array}{c}\text { 98.9 PCE } \\
99.4 \mathrm{TCE} \\
98.8 \mathrm{DCE} \\
100 \mathrm{VC}\end{array}$ & $\begin{array}{l}2 \text { years and } \\
4.67 \text { months }\end{array}$ & $\$ 335,880$ & $\$ 54,000$ & $\$ 389,880$ & $\$ 4.50$ \\
\hline $\begin{array}{c}\text { Potassium } \\
\text { Permanganate }\end{array}$ & $450 \mathrm{yd}^{3}$ & $\begin{array}{l}17,000 \mathrm{PCE} \\
830 \mathrm{TCE} \\
120 \mathrm{DCE} \\
1,170 \mathrm{VC}\end{array}$ & $\begin{array}{c}\text { Rebound of } \\
\text { contaminant } \\
\text { levels }\end{array}$ & $\begin{array}{c}\text { Not } \\
\text { provided }\end{array}$ & $\$ 243,800$ & $\begin{array}{l}\$ 31,800 \text { every } \\
3 \text { months }\end{array}$ & $\begin{array}{l}\text { No time } \\
\text { provided for } O \\
\& M \text { cost }\end{array}$ & \\
\hline $\begin{array}{l}\text { Fenton's } \\
\text { Process }\end{array}$ & $103,000 \mathrm{yd}^{3}$ & $\begin{array}{c}\text { gw } 21.5 \mathrm{PCE} \\
440 \mathrm{TCE} \\
1,400 \mathrm{DCE} \\
21 \mathrm{VC} \\
\text { soil } 530 \mathrm{PCE} \\
73 \mathrm{TCE} \\
35 \mathrm{DCE}\end{array}$ & $\begin{array}{l}\text { Rebound of } \\
\text { contaminant } \\
\text { levels }\end{array}$ & 2 years & $\begin{array}{l}\text { \$224,964 did not } \\
\text { include soil } \\
\text { excavation }\end{array}$ & $\begin{array}{c}\$ 8,316 \text { annual } \\
\text { monitoring }\end{array}$ & $\$ 241,596$ & $\$ 2.50$ \\
\hline $\begin{array}{l}\text { Peroxide } \\
\text { Activated } \\
\text { Sodium } \\
\text { Persulfate }\end{array}$ & & $\begin{array}{c}\text { gw } 39,772 \\
\text { Chlorinated } \\
\text { solvent } \\
\text { soil } 106,283 \\
\text { Chlorinated } \\
\text { solvent }\end{array}$ & $\begin{array}{l}\text { gw } 83 \\
\text { soil } 93\end{array}$ & 4 months & & & $\begin{array}{l}\text { Cost not } \\
\text { provided }\end{array}$ & \\
\hline SVE & $310 \mathrm{yd}^{3}$ & $\begin{array}{c}\text { gw 19.9 PCE } \\
27.4 \text { TCE } \\
66.3 \mathrm{DCE} \\
\text { soil 190 PCE }\end{array}$ & $\begin{array}{l}\text { All contaminants } \\
\text { reduced to: } \\
\text { gw less than } 3 \\
\text { ppb } \\
\text { soil less } 30 \mathrm{ppb}\end{array}$ & 4 months & $\$ 221,863$ & $\$ 32,303$ & $\$ 254,166$ & $\$ 815$ \\
\hline $\begin{array}{l}\text { Six-Phase } \\
\text { Heating }\end{array}$ & $5300 \mathrm{yd}^{3}$ & $\begin{array}{l}\text { gw } 645,000 \text { TCE } \\
\text { soil } 125,459 \mathrm{TCE}\end{array}$ & $\begin{array}{l}\text { gw } 99 \\
\text { soil } 98\end{array}$ & 7 months & & & $\$ 6,678,000$ & $\$ 1,250$ \\
\hline
\end{tabular}


Table IV- 1 Performance and Cost for Technology Case Studies

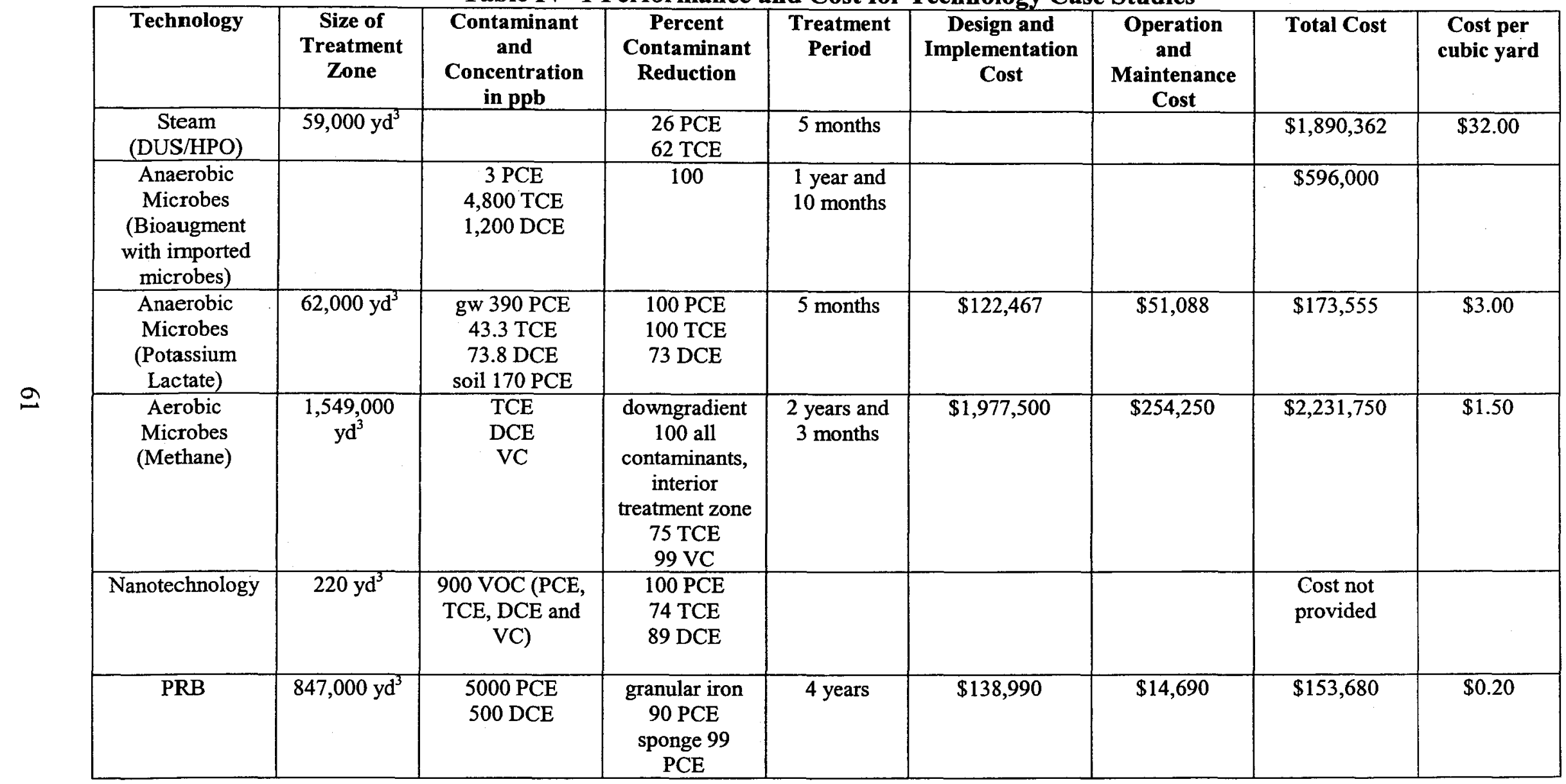


The anaerobic bioremediation at Dover Air Force Base and extremophile case studies were not listed in Table IV-1, because of the lack of information regarding those studies, although they will be treated to in Chapter V.

All case studies for potassium permanganate found in EPA Abstracts of Remediation Case Studies and SCRD had incomplete information. The case study presented in Chapter III was the most complete case study on potassium permanganate found from those sources. The case study lacked the time of the study, the time of the treatment period and percent contaminant reduction. The cost per cubic yard would be $\$ 834$ if the treatment was conducted for one year. The cost would be more if the treatment period was longer. All case studies for potassium permanganate referred to contaminant rebound after the treatment process stopped. Some of the case studies for the other ISCO methods (ozone and Fenton's) experienced a contaminant rebound after the treatment period. The rebound of contaminant levels in the groundwater could be caused by the residual DNAPL dissolving after the dissolved phase contaminants are oxidized or the contaminants sorbed in the soil migrate into the groundwater.

In addition to the review of case studies, vendor contacts were made to get cost information for remediation technologies potentially to be used at PGDP. Contact was made by email to Doug Carvel, PE, president of MECX on July 14, 2005 for cost information on ISCO. The following four paragraphs were his reply on July 16, 2005. "I am an approved supplier and applicator for Carus Chemical Corp. I can provide you with an accurate cost comparison between activated sodium persulfate using various activation methodologies, and permanganate. Unfortunately cubic yard estimates are meaningless. What I need is surface area and depths throughout the treatment zone. The 
reason for this is that for these technologies, the chemical costs will vary linearly with thickness of the treatment zone but the labor and equipment will remain constant up to a certain point. With Perozone or just ozone, the labor is a minute portion of the project and the equipment and $\mathrm{O} \& \mathrm{M}$ is the major costs. With the other ISCO technologies the labor can be as high as $60 \%$ of the total cost or as low as $30 \%$. Another difference is ozone delivers very little oxidant per day and therefore operates for a much longer time and can be used as little or a great as needed just by extending the time. With other technologies, in order to get sufficient contact, the minimum in situ concentration is pretty much the same for $1000 \mathrm{ppb}$ as it is for $2 \mathrm{ppb}$. Roughly the solubility limit of potassium permanganate 4$5 \%$ and $1-2 \%$ for activated sodium persulfate.

Regarding the labor cost, the vendors that inject the chemicals under pressure, waste chemical, displace the contaminants, and do not get effective mixing and contact. To estimate the labor we need to estimate the time in the field. This is based on the infiltration rate which is related to the screened interval as well as the permeability and the ability to set up a network of extraction and injection points to get optimum distribution without displacement.

The size of the plume appears to control which technology is the most efficient for a given site as well as the nature of contamination. If large amounts of the contaminant mass are sorbed, only the peroxide based treatments are truly effective. This is due to peroxides ability to desorb and dissolve mass. No other technology even gets close. Using peroxide with permanganate is an option if used first in addition to peroxide activated persulfate or perozone. 
Sorry, you quest has too many variables to be simplified. The fact is if you have a large sorbed mass, the technologies are limited to peroxide combinations. If you have no sorbed mass, distribution is the key not the oxidant for the target contaminants and if labor controls the cost there is virtually no difference between permanganate and persulfate. If the chemical controls the cost for larger plumes, then you have to look more closely at the chemical and as a side, you have to look at if the chemical is from the USA or China. There is a large variation in these costs and it can affect the outcome of the evaluation."

The contact for bioremediation was Dick Raymond of Terra Systems Incorporated. Mr. Raymond gave a presentation on in situ bioremediation of TCE at the University of Louisville on June 2, 2005. He mentioned that with certain site conditions, bioremediation can be the most cost-effective remediation technology for TCE and if site conditions do not favor bioremediation the ISCO and PRBs should investigated. This statement does seem to agree with the cost per cubic yard of treatment zone in Table IV-1.

The vendor contacts made for PRBs were Robbie Laird of C3 Environmental and John Vogan of EnviroMetal Technologies. C3 Environment installs the patented sheet pile Waterloo Barrier for funnel and gate PRBs. EnviroMetal has a patented iron treatment medium used in PRBs that is very effective for TCE and can immobilize Tc-99. 


\section{CONCLUSIONS AND RECOMMENDATIONS}

\section{A. Conclusions}

The evaluation of the technologies for performance and cost in Chapter IV is not meant to be used for choosing a remediation technology and estimating a cost for remediation at PGDP. The purpose of the evaluation is to see what technologies are the most practical and determine what site conditions must be evaluated at PGDP to allow the most efficient use of the most practical technologies. Once site assessment determines which technology should be selected, then cost and treatment time can be determined.

1. Six-phase heating proved to be a very effective treatment at high contaminant concentration levels but has the highest overall cost, twenty times more expensive per cubic yard of treatment zone than rotary treatment which is just as effective at similar contaminant concentration levels. Both of these methods would have implementation difficulty if their application is near buildings, buried utilities or any other obstruction.

2. SVE may not be as difficult to implement as six-phase heating or rotary treatment but is the second most expensive treatment method. At higher contaminant concentration levels similar to those in the six-phase heating and rotary treatment studies, 
SVE would be more than $\$ 815$ per cubic yard because of the increase in operation and maintenance cost.

3. Steam (DUS/HPO) did not perform well in reducing contamination level, although if the system ran longer more contaminants would be reduced but with higher operation and maintenance cost.

4. The low cost per cubic yard for the PRB case study can be misleading since the percent contaminant reduction refers to the effluent during the life of the PRB and not the entire treatment zone. PRBs can be a very cost effective method for preventing contaminant source or plume migration.

5. The ISCO and bioremediation methods have a significantly lower cost per cubic yard of treatment zone and the case studies showed how some of these methods can be very effective in treatment of VOCs.

\section{ISCO Methods}

Permanganate seems to be a questionable choice for an ISCO method because of the lack of a successful case study proving its effectiveness in reducing contamination levels. A rebound in contaminant concentration took place after permanganate concentrations decreased. The operation and maintenance cost was much higher than for the other ISCO methods.

The Fenton's process case study had the lowest overall cost of the ISCO methods but exhibited contaminant rebound problems similar to those cited in the permanganate case study.

The C-Sparge with ozone case study had complete information showing 99 percent reduction in contaminant levels at a cost of $\$ 4.68$ per cubic yard. The contamination level 
of the C-Sparge study was $24,944 \mathrm{ppb}$ total VOCs which is about 26 times less than the TCE concentration in the six-phase heating study. If the total cost of the C-Sparge study is calculated by multiplying the operation and maintenance cost by 26 and adding the design and implementation cost, the cost per cubic yard is less than $\$ 21$ which is 60 time less than six-phase heating.

The Peroxide activated sodium persulfate case study did not provide cost data but did display an impressive performance in significantly reducing high VOC concentrations in a very short treatment period (four months). The 93 percent reduction in soil contamination confirmed what Carvel said about persulfate's ability to desorb and dissolve contaminant mass. (as given on p. 62 herein)

\section{Bioremediation}

The bioremediation case studies showed that under certain site conditions microbes can be utilized to remediate groundwater contaminated with VOCs at a very low cost compared to other technologies.

\section{Qualitative Observation}

From the process of searching through case studies, it was observed that the use of microbes with cometabolites, ISCO methods and PRBs became a very popular as a remediation choice over the past four years. There was a lack of case studies involving the other technologies during the same time period.

\section{B. Recommendations}

The site assessment parameters outlined in Section II-K should be used to determine the feasibility of using bioremediation. It is unlikely that bioremediation would 
be feasible in the source zone because of the high levels of contamination. If the plume area conditions are conducive to using microbes for treatment of TCE, then bioremediation would be the most practical technology choice. Another advantage of bioremediation is that if anaerobic reduction is used, it will immobilize the Tc-99. If the plume has too many restrictions for bioremediation the ISCO methods should be investigated. Despite the contaminant rebound problems with permanganate and Fenton's process, they could still be implemented successfully in the plume area where undissolved and sorbed contaminant mass is not a concern. In the source zone where large amounts of undissolved and sorbed contaminant mass could exist, ozone and persulfate ISCO methods should be investigated.

The soil fracturing case study cited in Section III-B showed that fracturing can improve remediation depending on what technology is the primary method. The study concluded that soil fracturing would enhance the ISCO using permanganate more than the other remediation technologies considered in that study. Small-scale tests could be conducted in the UCRS using the selected ISCO or bioremediation methods with and without fracturing to determine if soil fracturing should be used.

Several technologies were described for TCE remediation, but for Tc-99, the only existing remediation is to immobilize Tc-99 using microbes (extremophiles, pages 29 and 52) to transform Tc-99 to its insoluble reduced state or using PRBs with reducing treatment media to prevent Tc-99 movement beyond the PRB.

The humic products described on page 30 have the potential to be a cost effective technology for TCE remediation but, more importantly, the humic products can immobilize Tc-99 more effectively. In a personal communication (Shulgin August 1, 2005), Dr. Alexander Shulgin, described how the humic material can bind to both the anion and cation 
forms of heavy metals. This ability of the humic material potentially could solve the problems encountered using microbes to immobilize Tc-99. The particular problems of microbes used to transform Tc-99 to an insoluble reduced state are restricting flow in the aquifer because of the precipitate, and the possibility of changes in the aquifer environment that would re-oxidize the Tc-99 causing it to become mobile again.

Dr. Shulgin also mentioned how the humic material not only provides a substrate and nutrient for microbes in bioremediation, but it also fosters a diversity of microbes and allows the microbes to remediate at higher contaminant concentrations. This combined method application possibly could allow bioremediation at the source zone contaminant levels.

\section{Technology Ranking}

Table V-1 ranks the recommended technologies and six-phase heating using a typical school grading system (A, B, C, D, and F) for various application factors.

Table V-1. Technology Ranking

\begin{tabular}{|c|c|c|c|c|c|c|c|}
\hline Technology & $\begin{array}{c}\% \\
\text { Reduction }\end{array}$ & $\begin{array}{c}\text { Implemen- } \\
\text { ability }\end{array}$ & $\begin{array}{c}\text { Source } \\
\text { Capable? }\end{array}$ & $\begin{array}{c}\text { Plume } \\
\text { Friendly? }\end{array}$ & $\begin{array}{c}\text { Time to } \\
\text { Treat }\end{array}$ & $\begin{array}{c}\text { Cost/ } \\
\text { Source }\end{array}$ & $\begin{array}{c}\text { Cost/ } \\
\text { Plume }\end{array}$ \\
\hline $\begin{array}{c}\text { Bioremedi- } \\
\text { ation }\end{array}$ & A & A & C & A & C & A & A \\
\hline $\begin{array}{c}\text { Bioremed. } \\
\text { w/HM }\end{array}$ & A & A & B & A & C & A & A \\
\hline $\begin{array}{c}\text { ISCO } \\
\text { [typical] }\end{array}$ & B & A & B & B & C & A & B \\
\hline $\begin{array}{c}\text { ISCO- } \\
\text { Persulfate }\end{array}$ & A & A & A & B & A & A & B \\
\hline $\begin{array}{c}\text { Six-Phase } \\
\text { Heating }\end{array}$ & A & C & A & D & A & D & F \\
\hline
\end{tabular}


VI. REFERENCES

AEHS Magazine 2001. http://www.aehsmag.com/issues/2001/spring/microbubble.htm

Andromalos, K. B., Jasperse, B. H., and Schindler, R. M., Current State of the Art InstallationTechniques for the In-Situ Reactive Wall Groundwater Treatment Systems. Geo-Con, Inc. Visited July 27, 2005 http://www.geocon.net/pdf/paper40.pdf

Alliance for Nuclear Accountability (ANA) 2004. Danger Lurks Below: The Threat to Major Water Supplies from US Department of Energy Nuclear Weapons Plant. http://www.ananuclear.org/waterreportpaducah.pdf

Block, P. A., Brown, R. A., and Robinson, D., "Novel Activation Technologies for Sodium Persulfate In Situ Chemical Oxidation" Proceedings of the Fourth International Conference on the Remediation of Chlorinated and Recalcitrant Compounds" 2004.

Cooperative Research and Development Agreement (CRADA) 1998. In-Situ Soil and Water Remediation at Contaminated Sites Utilizing a New Form of Humic Matter Called "Humosorb". CRADA No.Y-1295-0356.

Current Environmental Solutions (CES): Six-Phase Heating The Rapid Remediation Power Tool. Visited July 27, 2005 http://www.cesiweb.com/powertool.htm

Fialka, J. J. 2004. Position Available: Indestructible Bugs to Eat Nuclear Waste. The Wall Street Journal, Nov.16.

Hem, J. D., Study and Interpretation of the Chemical Characteristics of Natural Water. Second Edition. Geological Survey Water-Supply Paper 1473. United States Government Printing Office. 1970.

Interstate Technology Regulatory Council (ITRC) Jan. 2005. Technical and Regulatory Guidance for In Situ Chemical Oxidation of Contaminated Soil and Groundwater. http://www.itrcweb.org/Documents/ISCO-2.pdf 
Interstate Technology Regulatory Council (ITRC) Feb. 2005. Technical/Regulatory Guidelines Permeable Reactive Barriers: Lessons Learned/New Directions. http://www.itrcweb.org/Documents/PRB-4.pdf

Istok, J. D., Senko, J. M., Krumholz, L. R., Watson, D., M. Bogle, M. A., Peacock, A., Chang, Y. J., White, D. C., 2004. In Situ Bioreduction of Technetium and Uranium in a Nitrate-Contaminated Aquifer. Environmental Science \& Technology, vol. 38, p. $468-475$.

Jacobs, J. A., "Hot-Spot Remediation Using In-Situ Jetting Technology", Environmental Bio-Systems, Mill Valley, CA, presentation at the National Association of Environmental Health and Science Annual Meeting, March, 2001,San Diego, California; abstracts. http://www.ebsinfo.com/Abstract5.pdf

Jacobs, J. A. and Testa S. M., "Design Considerations for In-Situ Chemical Oxidation Using High Pressure Jetting Technology" Preprint for an article to be featured in AEHS April, 2003 http://www.ebsinfo.com/chemical_oxidation.pdf

Kerfoot Technologies: Frequently Asked Questions. Visited July 27, 2005 http://www.kerfoottech.com/doc.php?12,0,67868pker64586,,index

Luo, Jian, 2005. Department of Civil and Environmental Engineering Stanford University, "Hydraulic Control and Reactive Transport Simulation for In-Situ Remediation of Uranium(VI)-Contaminated Groundwater" Seminar at University of Kentucky, April 25. Personal Communication.

Major, D. W., McMaster, M. L., and Cox, E. E., (GeoSyntec Consultants, Guelph, Ontario, Canada), Lee, B. J. and Gentry, E. E., (Science Applications International Corporation, San Antonio, TX), Hendrickson, E., (Dupont, Delaware) Edwards, E., and Dworatzek, S., (University of Toronto), Successful Field Demonstration of Bioaugmentation To Degrade PCE and TCE to Ethene. Proceedings of the Groundwater Quality 2001 Conference held at Sheffield, UK, June 2001.

MECX CleanOx Application Chlorinated Solvent Manufacturing Facility St. Marys, Pennsylvania Visited July 30, 2005 http://www.mecx.net/CleanOX/St\%20\%20MarysPA-Facility.pdf

State Coalition for Remediation of Drycleaners (SCRD) Site Profiles. Visited July 29, 2005. http://www.dryclean.org/profiles

Suthersan, S. S., "Figure 3.1 Soil Vapor Extraction", Remediation engineering: design concepts, Boca Raton: CRC Press LLC, 1999.

Technical Advisory Group (TAG) Paducah Project Innovative Treatment Remediation Demonstration Program (ITRD) April 7, 2000. Sandia National Laboratories, Albuquerque, New Mexico. 
United States Department of Energy (US DOE) 2003. Final Report Six-Phase Heating Treatability Study at the Paducah Gaseous Diffusion Plant. Report No.

DOE/OR/07-2113\&D1 Office of Environmental Management.

United States Department of Energy (US DOE) 2001. Feasibility Study for the Groundwater Operable Unit at Paducah Gaseous Diffusion Plant Paducah, Kentucky Volume 1. Main Text. Report No. DOE/OR/07-1857\&D2, Office of Environmental Management.

United States Department of Energy (US DOE) 2000. Remediation of DNAPLs in Low Permeability Soils. Report No. DOE/EM-0550, Office of Environmental Management.

United States Department of Energy (US DOE) 1999. Bench Scale In-Situ Chemical Oxidation Studies of Trichloroethene in Waste Area Grouping 6 at the Paducah Gaseous Diffusion Plant Paducah, Kentucky. Report No. Doe/OR/07-1788\&D1, Office of Environmental Management.

United States Department of Labor Bureau of Labor Statistics CPI Inflation Calculator. Visited August 2, 2005. http://data.bls.gov/cgi-bin/cpicalc.pl

United States Environmental Protection Agency (US EPA) June 2004. Abstracts of Remediation Case Studies Vol. 8. Report No. EPA 542-R-04-012, Member Agencies of the Federal Remediation Technologies Roundtable.

United States Environmental Protection Agency (US EPA) May 2004. How to Evaluate Alternative Cleanup Technologies for Underground Storage Tanks Sites. Report No. EPA 510-R-04-002, Solid Waste and Emergency Response.

United States Environmental Protection Agency (US EPA) July 2003. Abstracts of Remediation Case Studies Vol. 7. Report No. EPA 542-R-03-011, Member Agencies of the Federal Remediation Technologies Roundtable.

United States Environmental Protection Agency (US EPA) June 2002. Abstracts of Remediation Case Studies Vol. 6. Report No. EPA 542-R-02-006, Member Agencies of the Federal Remediation Technologies Roundtable.

United States Environmental Protection Agency (US EPA) May 2001. Abstracts of Remediation Case Studies Vol. 5. Report No. EPA 542-R-01-008, Member Agencies of the Federal Remediation Technologies Roundtable.

United States Environmental Protection Agency (US EPA) 2000. Engineered Approaches to In Situ Bioremediation of Chlorinated Solvents: Fundamentals and Field Applications. Report No. EPA 542-R-00-008, Solid Waste and Emergency Response. 
Westinghouse Savannah River Company (WSRC) 2001. Evaluating DNAPL Source and Migration Zones: M-Area Settling Basin and the Western Sector of A/M Area, Savannah River Site (U).

Zhang, Wei-xian, 2003. Department of Civil and Environmental Engineering, Lehigh University, Nanoscale iron particles for environmental remediation: An overview. Journal of Nanoparticle Research 5: 323-332. 
APPENDIX A - ITRD COST AND PERFORMANCE ESTIMATES 
Table A-1 ITRD Cost and Performance Estimates for Application at Paducah

\begin{tabular}{|c|c|c|c|c|c|c|c|c|c|c|}
\hline 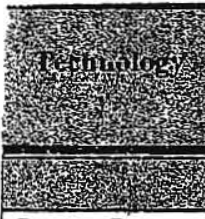 & Nisy & 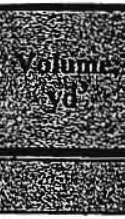 & 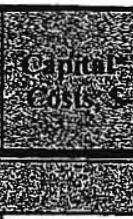 & s. & 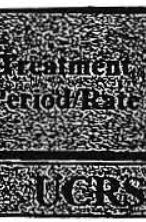 & (5). & 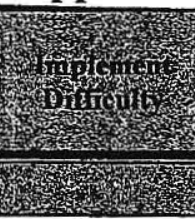 & 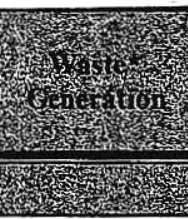 & 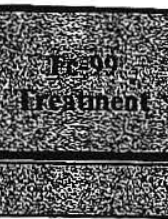 & 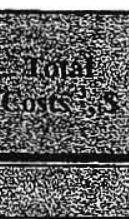 \\
\hline $\begin{array}{l}\text { Rotary Steam } \\
\text { (In-situ } \\
\text { Fixation) }\end{array}$ & $>100$ & 10,000 & $0.2 \mathrm{M}$ & & $\begin{array}{c}2 \mathrm{mo} / 250 \\
\mathrm{yd}^{3} / \mathrm{day}\end{array}$ & $\sim 5-10$ & $\begin{array}{l}\text { Low (in easy } \\
\text { access) }\end{array}$ & $\begin{array}{l}\text { PPE and } \\
\mathrm{NaCl} \text { solution }\end{array}$ & $\begin{array}{c}\text { Partial } \\
\text { recovery if } \\
\text { condensate } \\
\text { is subjected } \\
\text { to IX }\end{array}$ & $0.55 \mathrm{M}$ \\
\hline & $>100^{\circ}$ & 40,000 & $\overline{0.2 \mathrm{M}}$ & $1.2 \mathrm{M}$ & $\begin{array}{c}7 \mathrm{mo} / 250 \\
\mathrm{yd}^{3} / \mathrm{day}\end{array}$ & $\sim 5-10$ & $\begin{array}{l}\text { High (utilities } \\
\text { probs.) }\end{array}$ & $\begin{array}{l}\text { PPE and } \\
\mathrm{NaCl} \text { solution }\end{array}$ & & $1.6 \mathrm{M}$ \\
\hline & $>1,000$ & 10,000 & $0.2 \mathrm{M}$ & $0.8 \mathrm{M}$ & $\begin{array}{c}4 \mathrm{mo} / 100 \\
\mathrm{yd}^{3} / \mathrm{day}\end{array}$ & $\sim 50$ & $\begin{array}{l}\text { High (utilities } \\
\text { probs.) }\end{array}$ & $\begin{array}{l}\text { PPE and } \\
\mathrm{NaCl} \text { solution }\end{array}$ & 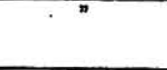 & $1 \mathrm{M}$ \\
\hline $\begin{array}{l}\text { Ozone Sparge } \\
\text { (IT Corp.) }\end{array}$ & $>100$ & 10,000 & ND & $40 / y d$ & $1 \mathrm{yt}$ & $\sim 5-10$ & $\begin{array}{l}\text { Med } \\
\text { (effectiveness } \\
\text { in clay) }\end{array}$ & Drill cuttings & No & $0.4 \mathrm{M}$ \\
\hline & $>100$ & 40,000 & ND & $35 / \mathrm{yd}$ & $1 \mathrm{yr}$ & $\sim 5-10$ & $\begin{array}{l}\text { Med } \\
\text { (effectiveness } \\
\text { in clay) }\end{array}$ & Drill cuttings & No & $1.4 \mathrm{M}$ \\
\hline & $>1,000$ & 10,000 & ND & $55 / \mathrm{yd}$ & $1 \mathrm{yr}$ & $\sim 20-30$ & $\begin{array}{l}\text { Med } \\
\text { (effectiveness } \\
\text { in clay) }\end{array}$ & Drill cuttings & $\begin{array}{c} \\
\text { No } \\
: \\
\end{array}$ & $0.55 \mathrm{M}$ \\
\hline $\begin{array}{l}\text { C-Sparge (KV } \\
\text { Assoc.) }\end{array}$ & $>100$ & 10,000 & $0.15 \mathrm{M}$ & $0.05 \mathrm{M}$ & $1 \mathrm{yr}$ & $\sim 1-5$ & $\begin{array}{l}\text { Med } \\
\text { (effectiveness } \\
\text { in clay) }\end{array}$ & $\begin{array}{l}\text { Drill cuttings; } \\
\text { GAC }\end{array}$ & $\begin{array}{c}\text { Possible } \\
\text { with resin in } \\
\text { well }\end{array}$ & $0.2 \mathrm{M}$ \\
\hline & $>100$ & 40,000 & $0.25 \mathrm{M}$ & $0.09 \mathrm{M}$ & $1 \mathrm{yr}$ & $\sim 5$ & 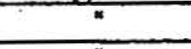 & " & 7 & $0.34 \mathrm{M}$ \\
\hline & $>1,000$ & 10,000 & $0.15 \mathrm{M}$ & $0.06 \mathrm{M} / \mathrm{yr}$ & $2 \mathrm{yrs}$ & $<50$ & 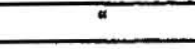 & " & $n$ & $0.27 \mathrm{M}$ \\
\hline Bio (WMI) & $>100$ & 40,000 & $0.35 \mathrm{M}$ & $0.5 \mathrm{M}$ & $1 \mathrm{yr}$ & $-1-5$ & $\begin{array}{l}\text { High: } \\
\text { Effectiveness } \\
\text { in clay?; } \\
\text { Fouling }\end{array}$ & $\begin{array}{l}\text { Trenching } \\
\text { Waste }\end{array}$ & No & $0.85 \mathrm{M}$ \\
\hline
\end{tabular}


Table A-1 ITRD Cost and Performance Estimates for Application at Paducah

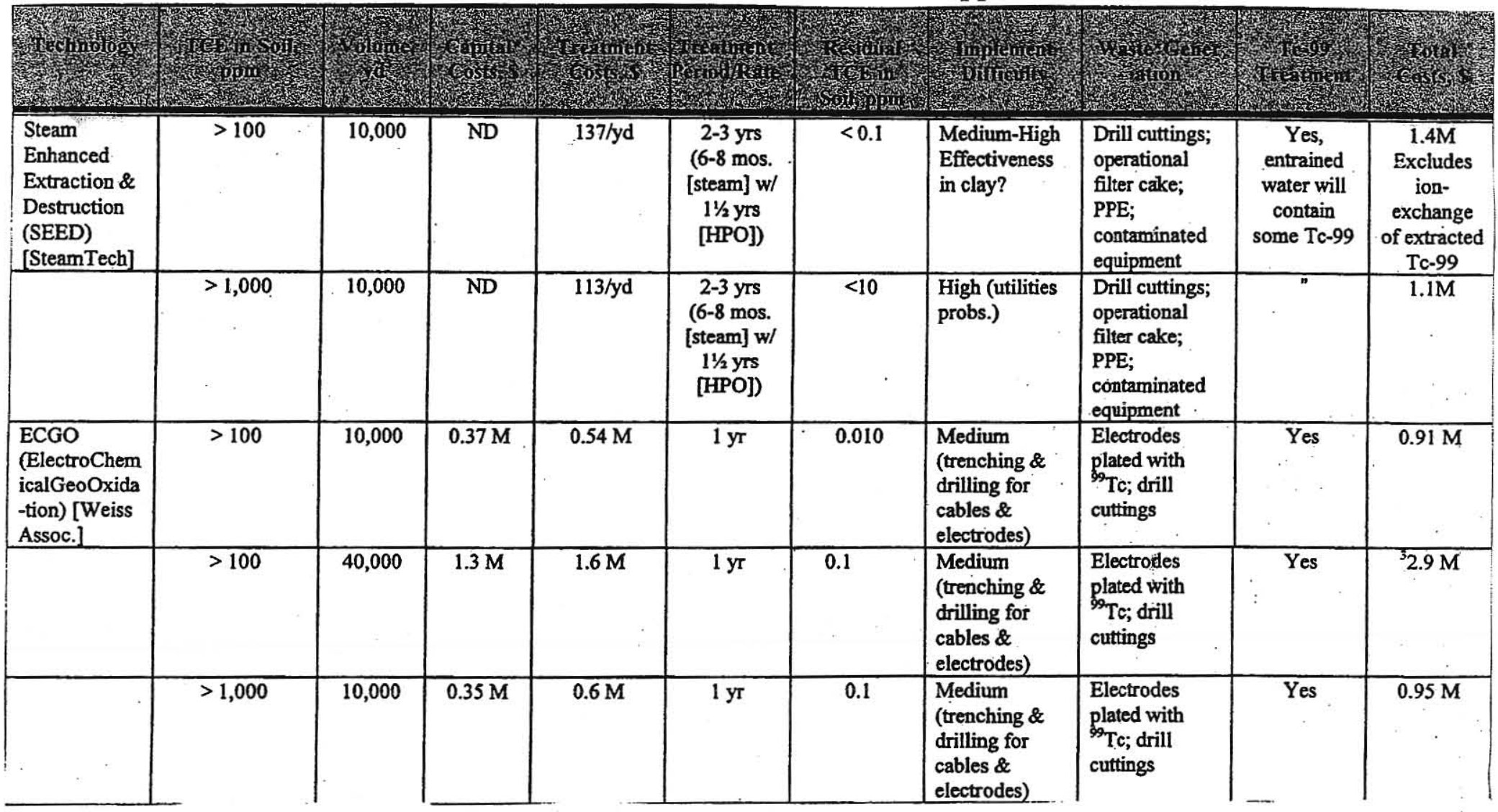


Table A-1 ITRD Cost and Performance Estimates for Application at Paducah

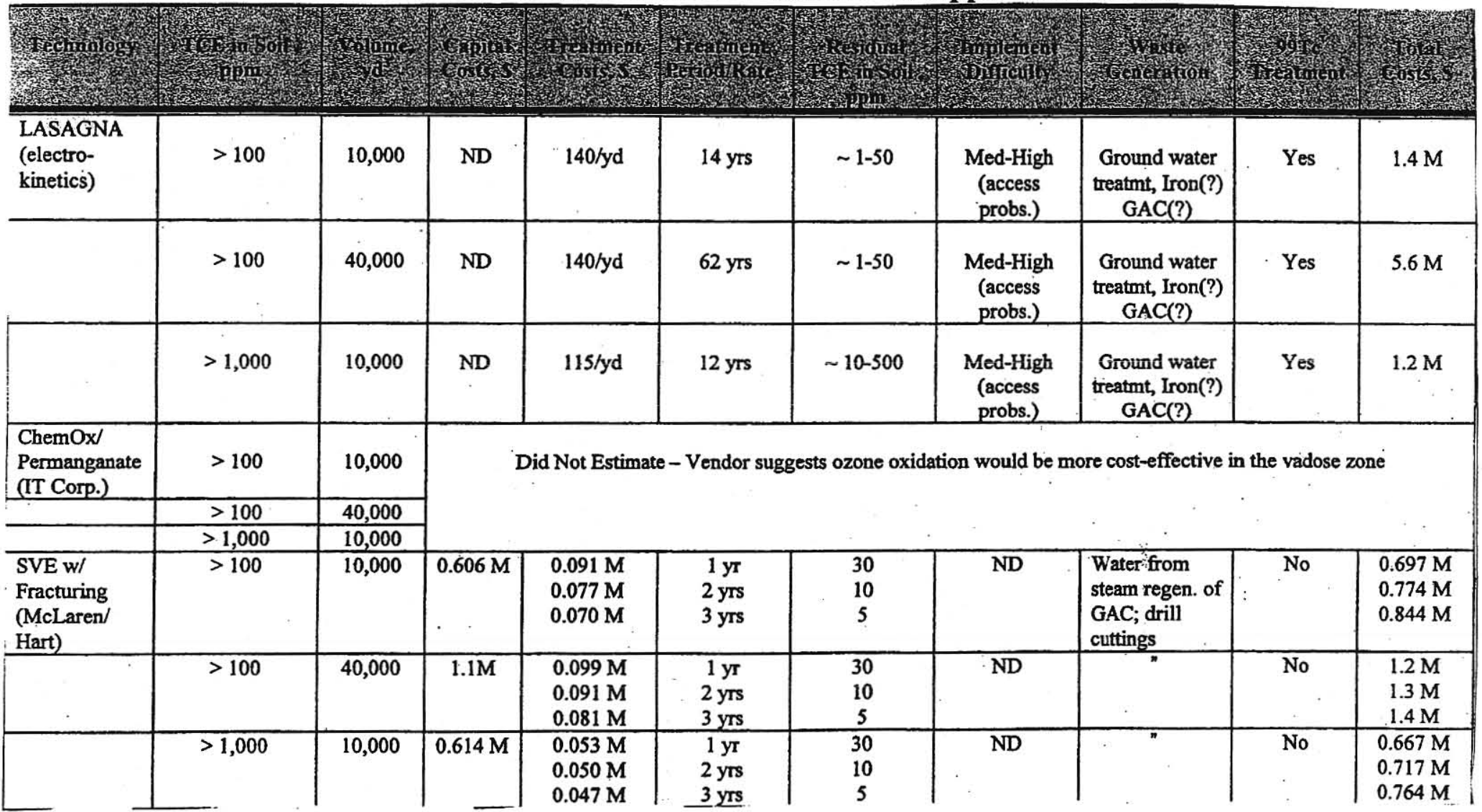


Table A-1 ITRD Cost and Performance Estimates for Application at Paducah

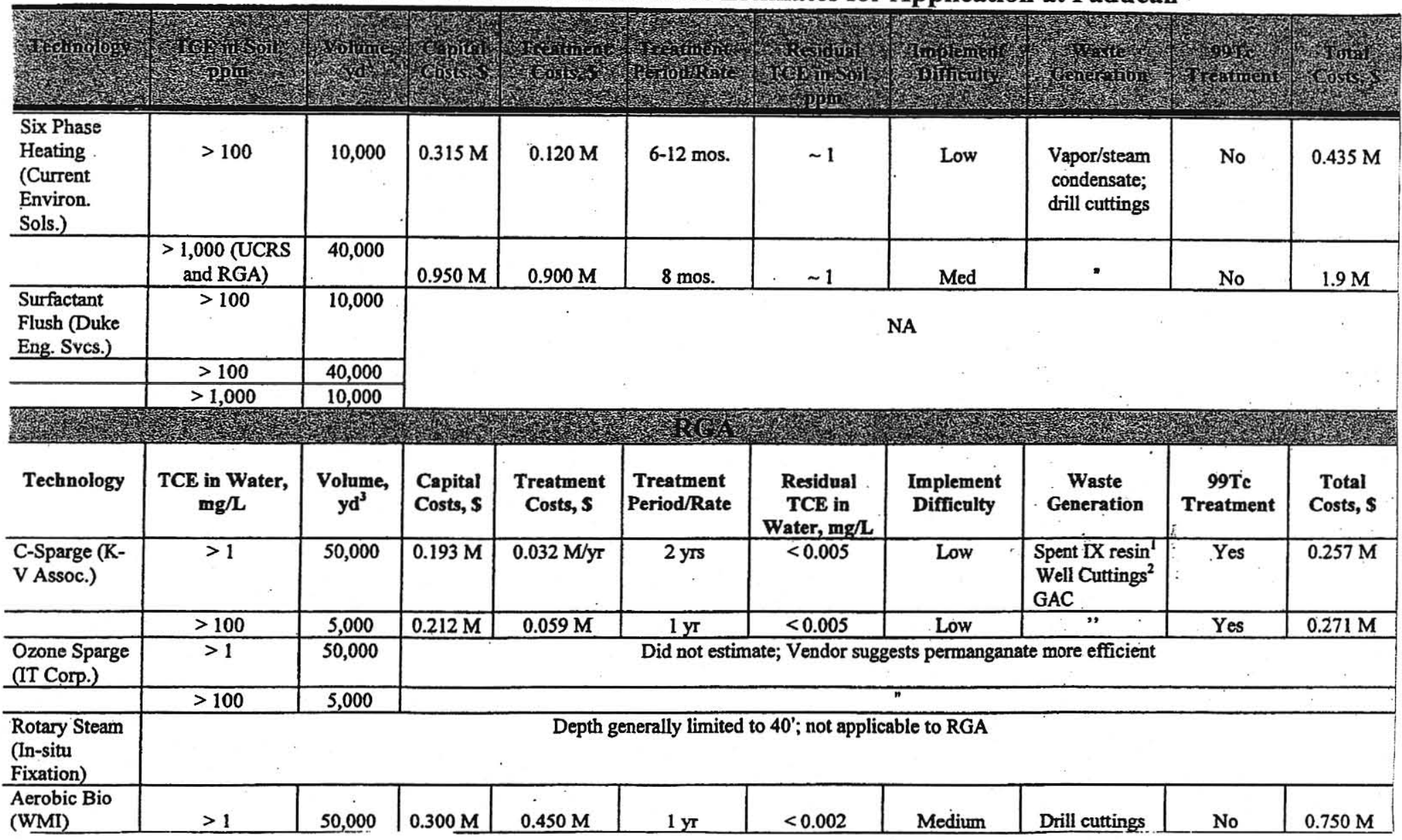


Table A-1 ITRD Cost and Performance Estimates for Application at Paducah

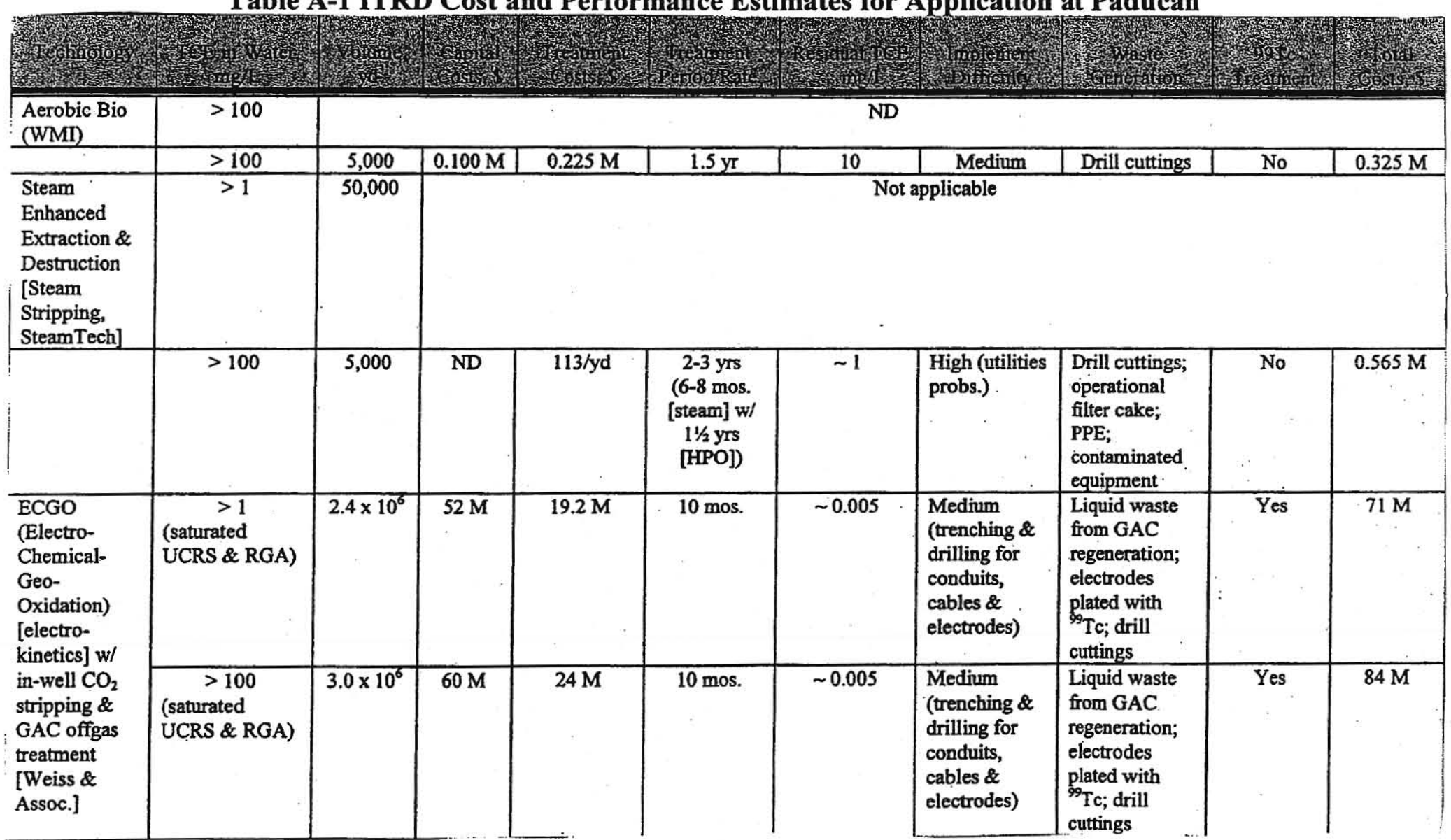


Table A-1 ITRD Cost and Performance Estimates for Application at Paducah

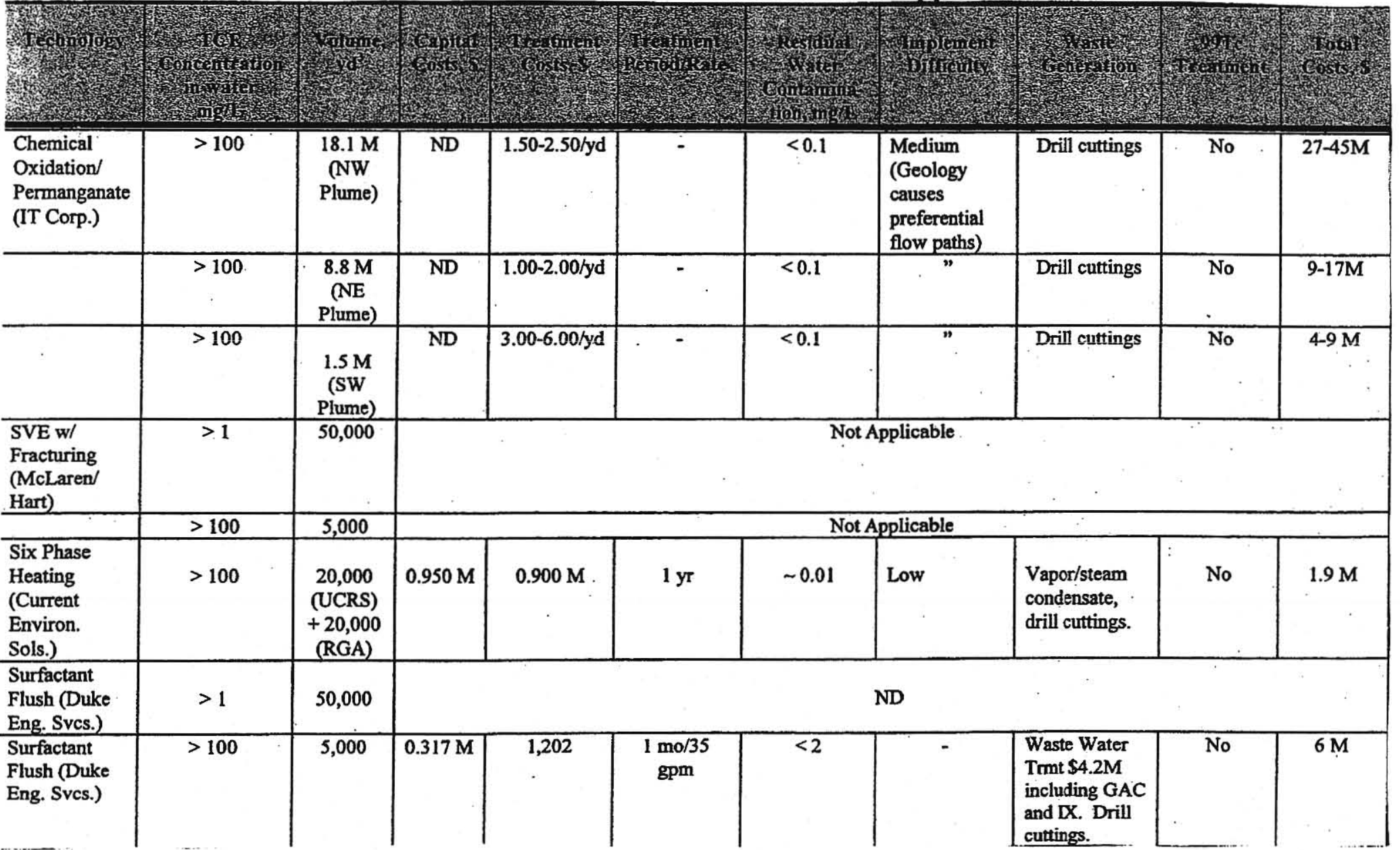


Table A-1 ITRD Cost and Performance Estimates for Application at Paducah

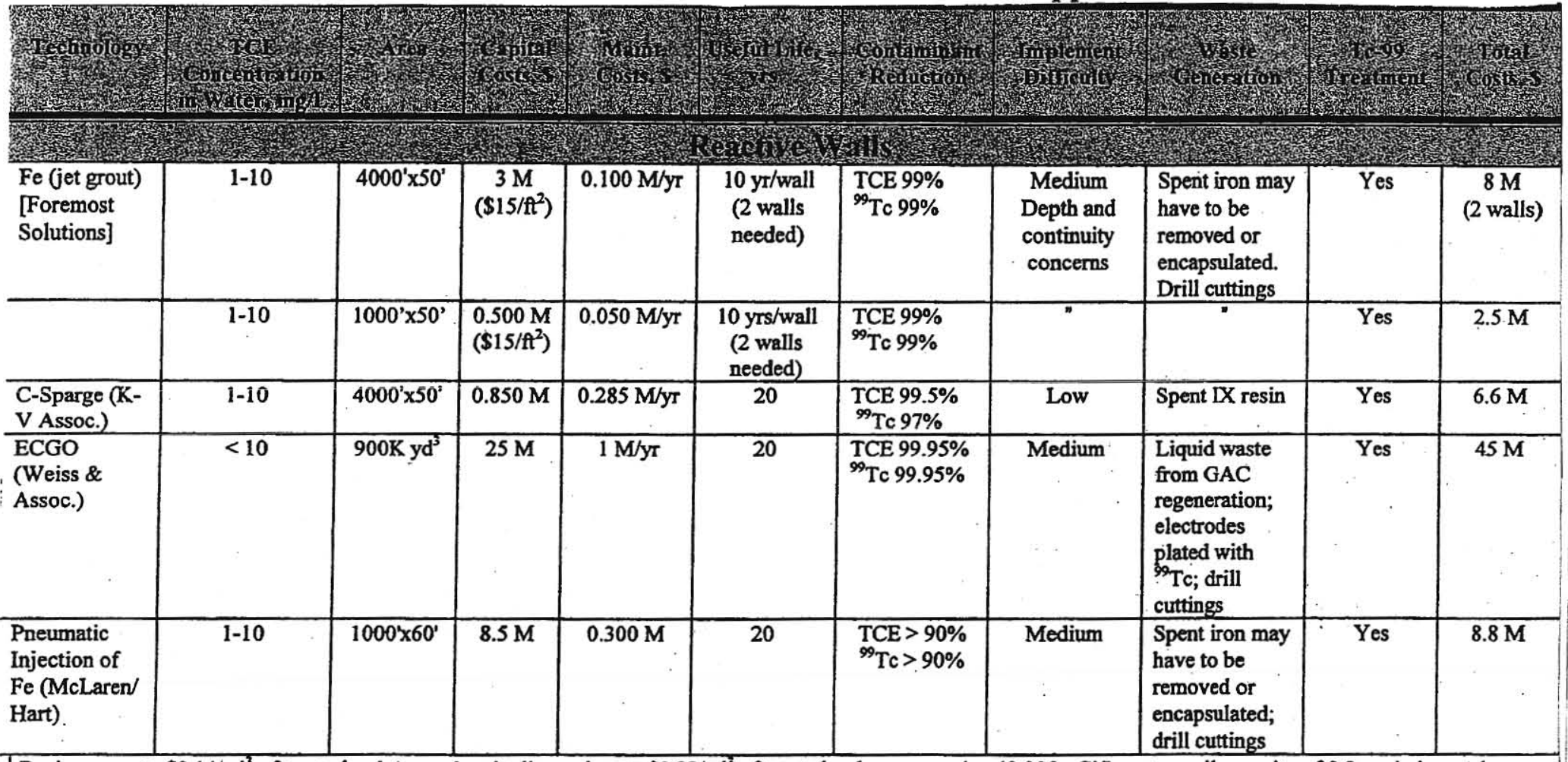

${ }^{\top}$ Resin use costs $\$ 0.14 / \mathrm{yd}^{3}$ of treated volume and resin disposal costs $\$ 0.22 / \mathrm{yd}^{3}$ of treated volume assuming $40,000 \mathrm{pCi} / \mathrm{L}$ water, soil porosity of 0.3 , resin ion exchange capacity of $0.0133 \mathrm{Ci} / \mathrm{R}^{3}$ and resin cost of $\$ 200 / \mathrm{A}^{3}$. Resin transportation cost is negligible. Decontamination water for drilling is less than 20 gallons per hole drilled. ${ }^{2}$ Assuming cuttings into RGA is mixed waste, cuttings disposal cost is $\$ 0.90 / y d^{3}$ of treated volume and transportation is $\$ 0.54 / y^{3}{ }^{3}$ of treated volume.

${ }^{3}$ Cost excludes horizontal drilling for access under buildings where applicable.

*Abbreviations: $\quad \mathrm{PPE}=$ Personnel Protection Equipment $\quad \mathrm{ND}=$ Not Determined $\quad \mathrm{NA}=$ Not Applicable

$$
\text { GAC }=\text { Granulated Activated Carbon } \quad \text { IX }=\text { Ion Exchange }
$$


Table A-2 ITRD Preliminary Technology Applications by Geologic Unit

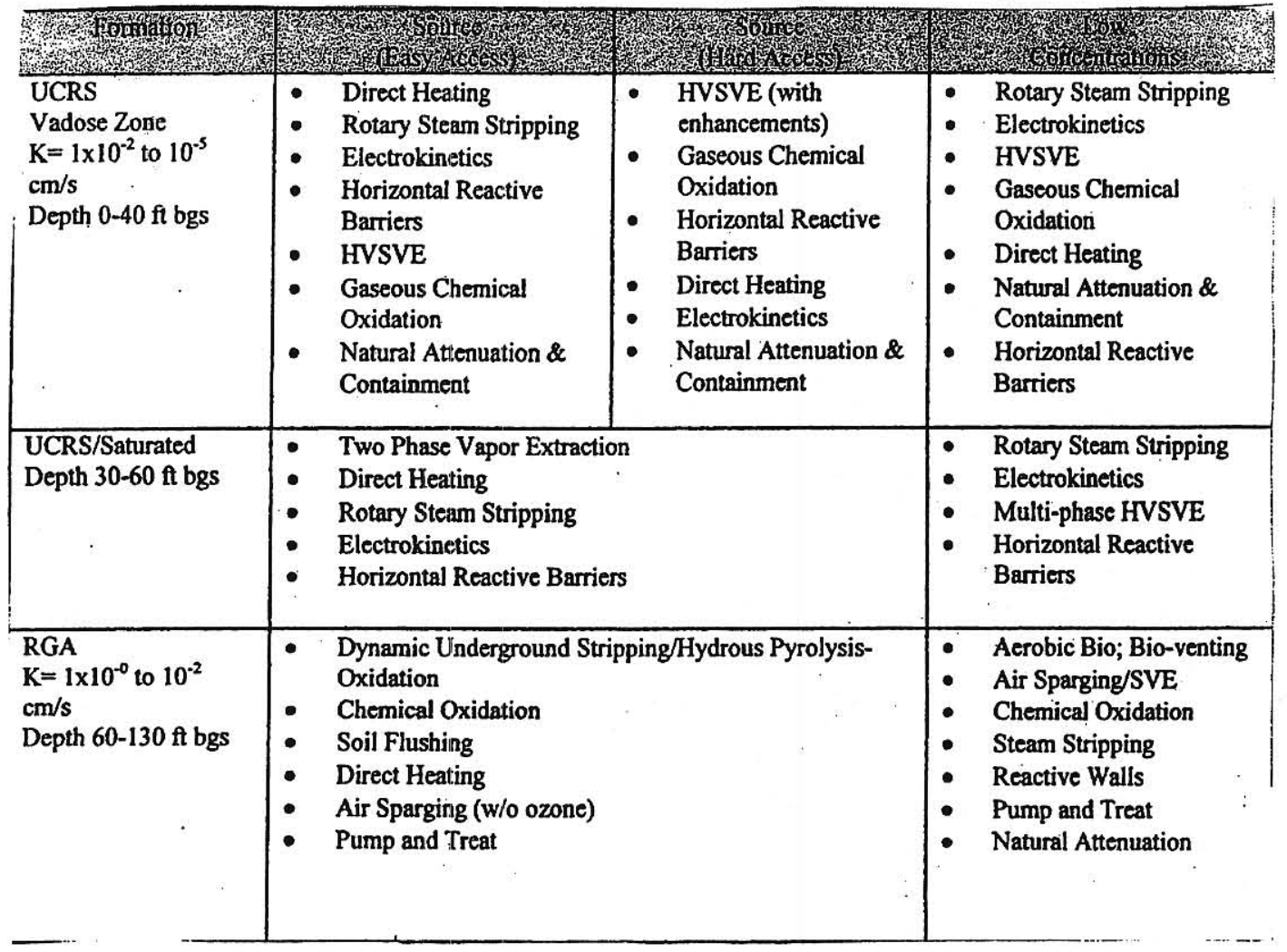


APPENDIX B - FENTON'S PROCESS 
When chemical oxidant $\mathrm{H}_{2} \mathrm{O}_{2}$ is injected at concentrations of 10 to $35 \%$ into the subsurface, it decomposes readily into reactive hydroxyl radicals $(\mathrm{OH})$ and water. The hydroxyl radical $(\mathrm{OH})$ in the subsurface can be used to rapidly mineralize hydrocarbon, solvent and other contaminants to water and carbon dioxide. This reaction is enhanced i the presence of iron. Iron is naturally occurring in soil and groundwater or can be added during the injection process, if needed. The reaction is based on the principle of Fenton': Chemistry where iron and hydrogen peroxide react to form hydroxyl radicals and other by-products as shown in Equation 1.

The double bonds, $\mathrm{C}=\mathrm{C}$, that characterize chlorinated ethenes are more reactive than the single $\mathrm{C}-\mathrm{C}$ bonds of chlorinated ethanes. Therefore, PCE and TCE are more susceptibl to chemical oxidation than TCA. Although all these chemicals are susceptible to chemical oxidation, relative resistance to oxidation from highest to lowest: PCE, TCE, vinyl chloride, phenantirene, benzene and hexane. The oxidation reaction for a common solvent, trichloroethene (TCE), forms several unstable daughter products (epoxides), the breaks down to ketones and aldehydes, finally yielding carbon dioxide, water and chloride ions (Suthersan, 2002). The oxidation of TCE is shown in Equation 2:

Equation 1:

$$
\begin{aligned}
& \mathrm{Fe}^{2}++\mathrm{H}_{2} \mathrm{O}_{2} \rightarrow \mathrm{OH}+\mathrm{OH}+\mathrm{Fe}^{3+} \\
& \mathrm{Fe}^{3}+\mathrm{H}_{2} \mathrm{O}_{2} \quad->\mathrm{Fe}^{2+}+\mathrm{HO}_{2} / \mathrm{O}_{2}{ }^{-}+\mathrm{H}^{+} \\
& \mathrm{Fe}^{3}+\mathrm{HO}_{2} \mathrm{O}_{2}-\mathrm{Pe}^{2}+\mathrm{O}_{2}+\mathrm{H}^{+} \\
& \text {(ton catalyst gets regenerted } \\
& \mathrm{OH}+\mathrm{H}_{2} \mathrm{O}_{2} \rightarrow \mathrm{HO}_{2} \mathrm{O}_{2}+\mathrm{H}_{2} \mathrm{O} \\
& \mathrm{OH}+\mathrm{Fe}^{2}+\rightarrow \mathrm{Fe}^{3}+\mathrm{OH} \\
& \mathrm{HO}_{2} / \mathrm{O}_{2}+\mathrm{Fe}^{2}++\mathrm{H}^{+}-\mathrm{Pe}^{3}+\mathrm{H}_{2} \mathrm{O}_{2} \\
& \text { OH - hydroxyl radical }
\end{aligned}
$$

Equation 2: $\quad 4 \mathrm{OH}^{\circ}+\mathrm{C}_{2} \mathrm{HCl}_{3}->2 \mathrm{CO}_{2}^{-}+3 \mathrm{Cl}+5 \mathrm{H}^{+}$

The hydroxyl radical that attacks the carbon-hydrogen bonds is capable of degrading many chlorinated solvents, chloroalkenes, esters, aromatics, pesticides and other recalcitrant compounds such as MTBE, PCP and PCB. The Fenton's chemistry reaction is highly complex, The iron cycles between the $\mathrm{Fe}$ (II) and Fe(II) oxidation states yields the hydroxyl radical and other by products (Suthersan, 2002). 
APPENDIX C - DR. ALEXANDER SHULGIN'S HMA EXPERIMENTS 


\section{Example 6}

There was carried out detoxication of soil samples taken in the vicinity of the condenser manufacturing works in the city of Serpukhov (Moscow region), said samples being polluted with polychlorinated biphenyl (PCB). Soil sample were taken from plowing areas $100 \times 100 \mathrm{~m}$ using the "envelope" technique .

Then put in a hothouse to be held there for 60 days at a constant temperature $(140 \mathrm{C})$ and humidity (70\% of a total soil moisture capacity). The HMA dose applied was from 0.1 to $10 \%$ in terms of dry matter of a total soil dry weight. Used as the control were soil samples free from the HMA. The HMA application procedure was repeated four times in succession. The starting PCB content was from 0.12 to $300 \mathrm{mg} / \mathrm{kg}$.

It was found that the soil samples featuring low PCB content $(0.12 \mathrm{mg} / \mathrm{kg}$ on the average) displayed a reduction in said content by $40-50 \%$ on the average for 60 days following the treatment with HMA, the most effective reduction of said content was observed in the range of the HMA doses applied from 0.3 to $5 \%$. With the HMA dose above $5 \%$ no perceptible difference was noted (except for the effect of "diluting" the soil samples).

It was also found that PCB content ( $300 \mathrm{mg} / \mathrm{kg}$ on the average) said content was found to have dropped by $30-34 \%$ for 60 days.

It was noted that with the temperature elevation to $240 \mathrm{C}$ the soil samples featuring a low PCB content $(0.12 \mathrm{mg} / \mathrm{kg}$ on the average) after having been held for 60 days at that temperature, displayed a $60-70 \%$ reduction in said content, while the soil featuring a high PCB content ( $300 \mathrm{mg} / \mathrm{kg}$ on the average) exhibited a $40 \backslash 50 \%$ reduction in the PCB content for the same period of time.

\section{Example 7}

As a result of industrial-economical activities, as well as warehousing and burial of domestic and industrial waste, an unfavorable ecological situation has arisen on some land areas consisting mainly in high levels of soil pollution and ground with heavy metals.

Decontamination and detoxication procedures of one of such areas were carried out in Moscow.

To select optimum HMA doses a number of experimental plots were laid on the area subject to decontamination, each plot being equal to $1 \mathrm{x} 1 \mathrm{~m}$. Plot No 1 was given one percent of HMA (in terms of dry matter) of a total soil weight, applied for a depth of $20 \mathrm{~cm}$, plot No2, $1.5 \%$ of HMA, plot No 3, 3\% of HMA, plot No 4 being the control.

Once HMA has been applied, the plots were dug over again for a depth of $20 \mathrm{~cm}$ so that HMA was spread uniformly over the profile of the polluted soil. Each of the plots was irrigated with water (8-10 1/sq.m), whereupon samples for chemical analysis.

In view of the fact that during soil tillage humic acids bind strongly the ions of toxic heavy metals by transforming them into stationary (water-insoluble) forms, the concentrations of 
metals in a mobile form were assigned for assessing the efficiency of the detoxication procedure performed. The results of the sample analysis are presented in Table 1.

\begin{tabular}{|c|c|c|c|c|c|c|c|}
\hline \multirow[b]{2}{*}{ Element } & \multirow[b]{2}{*}{ Buffer type } & \multirow{2}{*}{$\begin{array}{l}\text { Form of } \\
\text { element }\end{array}$} & \multirow[b]{2}{*}{ MAC } & \multicolumn{4}{|c|}{ Heavy metals content, $\mathrm{mg} / \mathrm{kg}$} \\
\hline & & & & $1 \%$ & $1.5 \%$ & $3 \%$ & control \\
\hline Zinc & $\begin{array}{l}\text { Ammonium- } \\
\text { acetate } \\
\text { buffer, } \\
\mathrm{pH}=4.8\end{array}$ & Mobile & 23,0 & 14,50 & 10,75 & 7,5 & 18,0 \\
\hline Manganese & $-"-$ & Mobile & 1500 & 7,05 & 6,59 & 5,90 & 7,14 \\
\hline Strontium & -"- & Mobile & & 27,5 & 19,1 & 3,3 & 33,3 \\
\hline Nickel & -"- & Mobile & 4,0 & 8,0 & 3,6 & 2,2 & 10,0 \\
\hline Cobalt & $\begin{array}{l}\text { Ammonium- } \\
\text { sodium } \\
\text { buffer, } \\
\mathrm{pH}=3.5\end{array}$ & Mobile & 5,0 & 8,2 & 4,0 & 2,1 & 8,3 \\
\hline Chromium & $\begin{array}{l}\text { Ammonium- } \\
\text { acetate } \\
\text { buffer, } \\
\text { pH=4.8 }\end{array}$ & Mobile & 6,0 & 16,0 & 5,0 & 3,5 & 21,0 \\
\hline Copper & -"- & Mobile & 3,0 & 4,0 & 2,5 & 2,0 & 5,0 \\
\hline Lead & -"- & Bulk & 30,0 & 33,0 & 22,5 & 10,3 & 35,0 \\
\hline Arsenic & -"- & Bulk & 2,0 & 10,0 & 1,6 & 0,5 & 14,0 \\
\hline Vanadium & -"- & Bulk & 150,0 & 6,6 & 5,0 & 3,9 & 7,6 \\
\hline Antimony & $-"-$ & Bulk & 4,5 & 0,50 & 0,42 & 0,33 & 0,52 \\
\hline Silver & - - & Bulk & & 0,42 & 0,30 & 0,24 & 0,47 \\
\hline Tin & -"- & Bulk & & 12,0 & 8,0 & 6,5 & 15,0 \\
\hline Cadmium & -"- & Bulk & & 1,01 & 0,83 & 0,48 & 1,02 \\
\hline
\end{tabular}

Table C-1

As is evident from Table C-1, the MAC values assigned for soil are attainable with a HMA application dose of about $1.5 \%$. As a result, the content of heavy metals capable of migrating into water medium and plants drastically diminishes. For an optimum HMA dose equal to $1.5 \%$ a land having an area of $1.8 \mathrm{ha}$ was subjected to detoxication. Soil samples were taken before and after the detoxication procedure using the HMA. Efficiency of the detoxication procedure is presented in Table $\mathrm{C}-2$. 


\begin{tabular}{|l|c|c|c|}
\hline \multicolumn{1}{|c|}{ Element } & $\begin{array}{c}\text { Mean concentration } \\
\text { before detoxication, } \\
\mathrm{mg} / \mathrm{kg}\end{array}$ & $\begin{array}{c}\text { Mean concentration } \\
\text { after detoxication, } \\
\mathrm{mg} / \mathrm{kg}\end{array}$ & $\begin{array}{c}\text { Efficiency, } \\
\text { percent }\end{array}$ \\
\hline Zinc & 25 & 10,1 & $60 \%$ \\
\hline Manganese & 7,7 & 6,24 & $19 \%$ \\
\hline Strontium & 45,6 & 5,78 & $87 \%$ \\
\hline Nickel & 9,6 & 2,7 & $72 \%$ \\
\hline Cobalt & 9,3 & 3,66 & $61 \%$ \\
\hline Chromium & 23,7 & 5,38 & $77 \%$ \\
\hline Copper & 4,3 & 2,46 & $43 \%$ \\
\hline Lead & 34,8 & 9,32 & $73 \%$ \\
\hline Arsenic & 12 & 1,76 & $85 \%$ \\
\hline Vanadium & 8,4 & 6,18 & $26 \%$ \\
\hline Antimony & 0,7 & 0,268 & $62 \%$ \\
\hline Tin & 12,2 & 5,28 & $57 \%$ \\
\hline Cadmium & 0,99 & 0,338 & $66 \%$ \\
\hline
\end{tabular}

Table C-2, Efficiency of the detoxication procedure

Analysis of the experimental evidence obtained from detoxication treatment of the polluted area enables one to conclude about a good efficiency of the soil detoxication procedure performed:

- content of mobile forms of cadmium, nickel and arsenic is reduced 5-6 times;

- content of mobile forms of chromium and strontium is reduced 4 times;

- content of mobile forms of lead, silver, tin and cobalt is reduced 3 times;

- content of mobile forms of zinc and copper is reduced twice, that of vanadium and antimony, 1.5 times.

In addition, content of manganese, strontium, zinc, copper, lead, cadmium, nickel, chromium, arsenic, silver, vanadium, antimony and tin in all soil samples taken after detoxication procedure are much below the MAC level.

\section{Example 8}

There was performed detoxication of samples of copper ore dressing rejects available from "Asarel-Medet" integrated ore-dressing plant (Bulgaria), said samples being taken from the "oxide" dump (samples No10) and from the "eastern" bank (samples No2).

An average copper content of sample No1 was $500 \mathrm{mg} / \mathrm{kg}$ with the $\mathrm{pH}$ value of 3.7 , that of sample No 2 was $700 \mathrm{mg} / \mathrm{kg}$, the $\mathrm{pH}$ value being 3.5 .

Acid reaction of the samples was neutralized by adding hydrated lime. It is found that an increase in $\mathrm{pH}$ value of the samples from $3.5-3,7$ to virtually neutral $\mathrm{pH}$ values equal to 7.88.5 have been attained with a lime dose approximately equal to $0.4 \%$ in terms of dry matter of a total dry weight of samples. However, as times went by, the $\mathrm{pH}$ of the lime-treated samples dropped down drastically. Thus, for instance, the $\mathrm{pH}$ value of lime-treated sample 
No1 was found to have dropped from 8.5 to 6.2 for 21 days and that of sample No 2, from, 8.2 to 4.2 for the same period of time.

It is also found that when neutralizing the acid reaction of the samples by adding hydrated lime thereto in an amount of $0.4 \%$ (in terms of dry matter) and bringing the $\mathrm{pH}$ value of said samples to 7.5-8.5 is followed by adding HMA thereto in an amount of from 0.15 to $12 \%$, much lower reduction in the $\mathrm{pH}$ values is observed. Moreover, with the HMA content within $10 \%$, the higher the HMA content of the samples the lower the $\mathrm{pH}$ reduction therein. Thus, for instance, with the HMA content of $0.15 \%$ in terms of dry matter of a total dry weight of samples \#1 the $\mathrm{pH}$ value is found to have dropped from 8.5 to 6.2 for 21 days; with the HMA content of $1.5 \%$ the pH value decreased from 8.5 to 7.6 , and with the HMA content of $3 \%$ the $\mathrm{pH}$ value decreased from 8.9 to 7.8 . However, with the HMA content of $10 \%$ and over no further changes in the $\mathrm{pH}$ value were observed.

The efficiency of detoxication of the waste products represented by samples No 1 and No 2 was studied upon adding hydrated lime thereto $(0.4 \%$ of the sample weight), as well as hydrated lime $(\sim 0.4 \%$ and the HMA in an amount of from 0.15 to $10 \%$. A toxic effect of the waste products on the growth and development of plants before and after adding hydrated lime and lime along with the HMA thereto was conducted in keeping with ISO Standard 11269-2. It was determined also a change in the species composition of microorganisms following adding lime and the HMA. The results of said studies including plant germination percentage (exemplified by barley), average plant height and biomass are given in Table C-3. 


\begin{tabular}{|c|c|c|c|c|c|}
\hline Nos & $\begin{array}{c}\text { Test } \\
\text { variants }\end{array}$ & $\begin{array}{c}\text { Seed } \\
\text { germinating } \\
\text { capacity, } \\
\text { percent of } \\
\text { total amount of } \\
\text { seeds sowed }\end{array}$ & $\begin{array}{c}\text { Percent of } \\
\text { control }\end{array}$ & $\begin{array}{c}\text { Average } \\
\text { height of } \\
\text { plant, percent } \\
\text { of control }\end{array}$ & $\begin{array}{l}\text { Average dry } \\
\text { biomass, } \\
\text { percent of } \\
\text { control }\end{array}$ \\
\hline $\begin{array}{l}\text { Original sample } \\
\text { No1 (control) }\end{array}$ & 32,6 & 100 & 100 & 100 & 2 \\
\hline $\begin{array}{l}\text { Sample No } 1+ \\
0.4 \% \text { of lime }\end{array}$ & 68,5 & 210 & 186 & 260 & 3 \\
\hline $\begin{array}{l}\text { Sample No1 }+ \\
0.4 \% \text { of lime }+ \\
0.75 \% \text { of } \mathrm{GM}\end{array}$ & 100 & 306 & 339 & 395 & 4 \\
\hline $\begin{array}{l}\text { Sample No } 1+ \\
0.4 \% \text { of lime }+ \\
1.5 \% \text { of } \mathrm{GM}\end{array}$ & 100 & 306 & 390 & 450 & 5 \\
\hline $\begin{array}{l}\text { Sample } \mathrm{No} 1+ \\
0.4 \% \text { of lime }+ \\
3 \% \text { of HMA }\end{array}$ & 100 & 306 & 410 & 563 & 6 \\
\hline $\begin{array}{l}\text { Original sample } \\
\mathrm{No} 2\end{array}$ & 0 & 0 & 0 & 0 & 7 \\
\hline $\begin{array}{l}\text { Sample } \mathrm{No2}+ \\
0.4 \% \text { of lime } \\
\text { (control) }\end{array}$ & 21,4 & 100 & 100 & 100 & 8 \\
\hline $\begin{array}{l}\text { Sample No } 2+ \\
0.4 \% \text { of lime }+ \\
0.75 \% \text { of HMA }\end{array}$ & 75,0 & 350 & 171 & 160 & 9 \\
\hline $\begin{array}{l}\text { Sample No } 2+ \\
0.4 \% \text { of lime }+ \\
1.5 \% \text { of HMA }\end{array}$ & 85,4 & 399 & 163 & 180 & 10 \\
\hline $\begin{array}{l}\text { Sample No } 2+ \\
0.4 \% \text { of lime }+ \\
3 \% \text { of HMA }\end{array}$ & 100 & 467 & 211 & 220 & \\
\hline
\end{tabular}

Table C-3

Note. Table 3 contains data for a HMA application dose of $0.75,1.5$ and $3 \%$. With said dose ranging from 0.15 to $1.5 \%$ there is observed a gradual increase in waste detoxication efficiency which reaches maximum values with HMA doses from 0.75 to $10 \%$. The exposure time is 21 days (till the stage of second leaf).

As is can be seen from Table 3 , it is the waste of sample $\# 2$ that proves to be most toxic so that seeds fail to germinate thereon. Lime application reduces toxicity but partially. By that reason the seventh test variant involving lime application is adopted for samples \#2 as the control.

Active microflora of the samples was studied both before and after lime and HMA application. 
Preliminarily a $1 \mathrm{~g}$ dose of a soddy-podzolic soil suspension was applied to all samples as a carrier of typical soil microorganisms. A great many sulfur bacteria of Thiobacillus ferooxidans and Leptospirillum ferooxidans genera was detected in the original (untreated) samples. No active forms of said sulfur bacteria are found after treatment thereof. 
APPENDIX D - COST INFLATION 
TABLE D-1 Cost Inflation Adjusted to the Year 2005

\begin{tabular}{|c|c|}
\hline Year & Percent Increase \\
\hline 1996 & 24 \\
\hline 1997 & 21 \\
\hline 1998 & 19 \\
\hline 1999 & 17 \\
\hline 2000 & 13 \\
\hline 2001 & 10 \\
\hline 2002 & 8 \\
\hline 2003 & 6 \\
\hline 2004 & 3 \\
\hline
\end{tabular}


VITA

The author was born on March 23, 1960 in Louisville, Kentucky to John N. Uhl Jr. and Mary C. Uhl. He graduated from Trinity High School in Louisville, Kentucky, in May 1978. He received a Bachelor of Arts in Biology from the University of Louisville in 1989 while working as a chemist in food science at Clarendon Flavor Engineering from September 1984 to October 1991. He owned and operated his own landscaping business from November 1991 to July 2004 while earning a Bachelor of Science in Civil Engineering from the University of Louisville in May 2004. In August 2005, Nick received a Master of Engineering Degree in Civil Engineering and Certification in Environmental Engineering from the University of Louisville. 